\title{
Advanced Biomaterials and Techniques for Oral Tissue Engineering and Regeneration-A Review
}

\author{
Anamaria Matichescu ${ }^{1}$, Lavinia Cosmina Ardelean ${ }^{2, *} \mathbb{C}^{\text {, Laura-Cristina Rusu }}{ }^{3}{ }^{1}$, \\ Dragos Craciun $^{3}$, Emanuel Adrian Bratu ${ }^{4, *}$, Marius Babucea ${ }^{3}$ and Marius Leretter 5 \\ 1 Department of Preventive Dentistry, Community and Oral Health, "Victor Babeș" University of Medicine \\ and Pharmacy Timisoara, 2 Eftimie Murgu Sq., 300041 Timisoara, Romania; matichescu.anamaria@umft.ro \\ 2 Department of Technology of Materials and Devices in Dental Medicine, "Victor Babeș" University of \\ Medicine and Pharmacy Timisoara, 2 Eftimie Murgu Sq., 300041 Timisoara, Romania \\ 3 Department of Oral Pathology, "Victor Babeș" University of Medicine and Pharmacy Timisoara, \\ 2 Eftimie Murgu Sq., 300041 Timisoara, Romania; laura.rusu@umft.ro (L.-C.R.); \\ craciun.dragosi@gmail.com (D.C.); babucea.marius@gmail.com (M.B.) \\ 4 Department of Implant Supported Restorations, "Victor Babeș” University of Medicine and Pharmacy \\ Timisoara, 2 Eftimie Murgu Sq., 300041 Timisoara, Romania \\ 5 Department of Prosthodontics, "Victor Babeș" University of Medicine and Pharmacy Timisoara, \\ 2 Eftimie Murgu Sq., 300041 Timisoara, Romania; mariusleretter@yahoo.com \\ * Correspondence: lavinia_ardelean@umft.ro (L.C.A.); ebratu@umft.ro (E.A.B.)
}

Received: 24 October 2020; Accepted: 19 November 2020; Published: 23 November 2020

\begin{abstract}
The reconstruction or repair of oral and maxillofacial functionalities and aesthetics is a priority for patients affected by tooth loss, congenital defects, trauma deformities, or various dental diseases. Therefore, in dental medicine, tissue reconstruction represents a major interest in oral and maxillofacial surgery, periodontics, orthodontics, endodontics, and even daily clinical practice. The current clinical approaches involve a vast array of techniques ranging from the traditional use of tissue grafts to the most innovative regenerative procedures, such as tissue engineering. In recent decades, a wide range of both artificial and natural biomaterials and scaffolds, genes, stem cells isolated from the mouth area (dental follicle, deciduous teeth, periodontal ligament, dental pulp, salivary glands, and adipose tissue), and various growth factors have been tested in tissue engineering approaches in dentistry, with many being proven successful. However, to fully eliminate the problems of traditional bone and tissue reconstruction in dentistry, continuous research is needed. Based on a recent literature review, this paper creates a picture of current innovative strategies applying dental stem cells for tissue regeneration in different dental fields and maxillofacial surgery, and offers detailed information regarding the available scientific data and practical applications.
\end{abstract}

Keywords: regenerative medicine; regenerative dentistry; tissue engineering; stem cells; biomaterials; scaffolds; growth factors; additive manufacturing; 3D printing

\section{Introduction}

The traditional standard techniques based on replacing missing or deteriorated tissue with autologous grafts from living donors or even cadavers are still used in dentistry as well as in other medical fields, despite their disadvantages, such as risk of infections and rejection following the transplantation procedure. An innovative alternative is provided by regenerative medicine, which aims to regenerate, repair, or replace tissues and to ensure restoration of their impaired function by combining tissue engineering with the self-healing ability of humans. In vitro engineering of tissues and organs involves the emerging field of biotechnology in a multidisciplinary approach together with medicine, materials science, cell and molecular biology, bioengineering, and genetics [1]. 
Tissue engineering is a term associated with regenerative medicine and is distinct in its focus on aspects regarding the engineering and manufacturing of replacement tissue, but regenerative medicine and tissue engineering are often treated as a single field of interest in the literature. Tissue engineering aims to create functional tissue or even organs using patients' own cells, offering an alternative method to grafts or transplants. This approach is being increasingly used in dental and maxillofacial reconstruction medicine, providing a new option for the reconstruction of teeth, periodontium, bones, oral mucosa, conjunctiva, skin, temporomandibular joint, both bone and cartilage as well as nerves, muscles, tendons, and blood vessels of the oral and maxillofacial area [2].

Tissue engineering can be used to regenerate tissue for specific defects, which represents a major advantage compared with other current treatments which have numerous disadvantages for patients like loss of sensorial and motor functionalities of craniofacial structures due to prosthetic alloplastic materials, high risk of infection, inflammation, requirement for lifelong immunosuppression, or unpredictable compatibility with the donor in the case of autologous grafts. Additionally, the unlimited available bioengineered resources do not require immunosuppression [3]. Tissue engineering is classically based on three pillars: (a) the cells (stem cells/progenitor cells), responsible for synthesizing the new tissue matrix; (b) the signaling/growth factors necessary to promote and facilitate the functionalities; (c) the biomaterial scaffolds, necessary for cell differentiation, multiplication, and biosynthesis, that act as an extracellular matrix (ECM) (Figure 1).

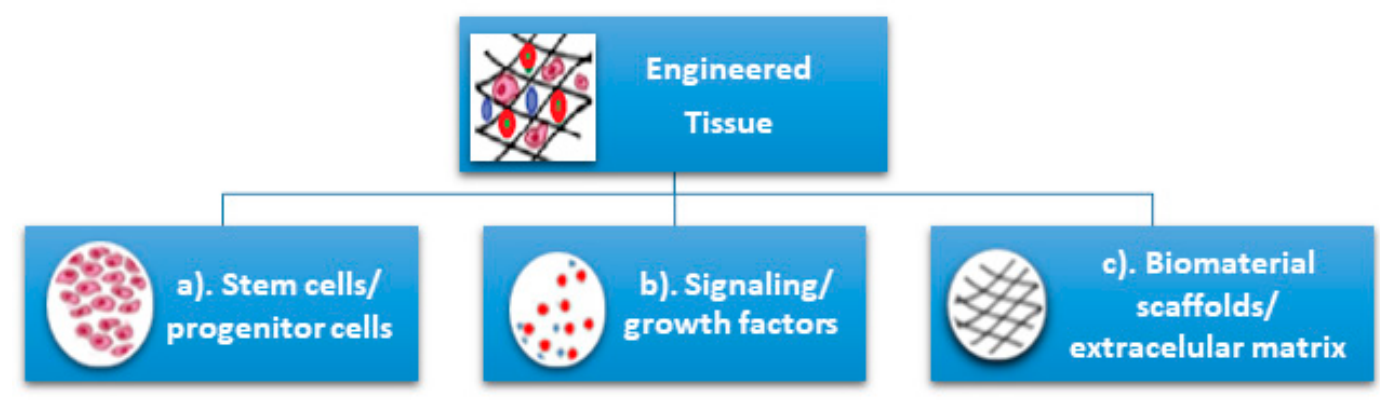

Figure 1. Classical pillars of tissue engineering: (a) the cells (stem cells/progenitor cells), (b) the signaling/growth factors, (c) the biomaterial scaffolds/extracellular matrix.

Cells communicate with their environment using different components to regenerate tissues by combining human cells with specific scaffold biomaterials. The biomaterial scaffolds provide templates for tissue regeneration and guide new tissues in their growth [4,5]. A successful approach in tissue engineering and regeneration implies that the combination of these three principles must be able to replace the damaged tissue and enable its function similarly to the original tissue or must be able to stimulate regeneration of the original tissue [6,7]. Several kinds of cells have been used in tissue engineering and regenerative medicine as reported in clinical studies, including stem cells, fibroblasts, chondrocytes, and keratinocytes originating from the same patient, another human, or animals [8].

The aim of this narrative review article is to approach this broad-spectrum subject in view of the literature from recent years specifically on the topic of potential orofacial stem cell usage in regenerative dentistry, both for hard and soft tissues. A large literature survey was performed on this topic in free-access digital archives of full-text articles (PubMed, Medline, Web of Science, and Google Scholar), with articles published between 2010-2020 being considered. More than 300 articles were referenced, with over $50 \%$ published in the last five years. The keywords used for searching were "regenerative dentistry", "tissue engineering", and "orofacial stem cells". A specific search was performed to identify clinical studies involving the application of dental stem cells for tissue regeneration in endodontics, periodontics, and maxillofacial surgery. 
2. Stem Cells, Biomaterials, and Scaffolds for Oral Tissue Engineering and Regeneration-Types, Sources, and Technologies

\subsection{Orofacial Stem Cells}

Stem cells (SCs) are defined as primitive, unspecialized, and pluripotent cells of the human body characterized by two major properties: production of other new stem cells and multidirectional differentiation into cells with a specific functionality, such as bone cells, skin cells, and blood cells [8,9]. Their presence was first reported in bone marrow [10].

SCs have powerful potential in medicine; their study has revealed important information about the complex processes of human body development. Due to these abilities, SCs have attracted interest regarding their use in the regeneration, repair, and functionality improvement of degenerated or injured tissue using implants of engineered tissue as well as biohybrid organs. The strategies involving the use of stem cells for tissue regeneration can be optimized using bioactive scaffolds or by adding various growth factors [11].

Considering their origin, physiological stem cells include embryonic stem cells (ESCs) from embryos and adult stem cells (ASCs) from adult tissue. Other types of stem cells are the perinatal stem cells, from amniotic fluid, and induced pluripotent stem cells (iPSCs) [12], obtained by transforming regular ASCs under genetic reprogramming. iPSCs, which are generated directly from a somatic cell, were pioneered by Yamanaka, in 2006. Shinya Yamanaka's discovery was awarded with the 2012 Nobel Prize, jointly with Sir John Gurdon, who, in 1962, demonstrated that the specialization of cells is reversible. The immature cell nucleus in an egg cell of a frog was replaced with the nucleus from a mature intestinal cell. This modified egg cell developed into a normal tadpole, proving that the DNA of the mature cell still had all the information needed to develop all cells in the frog [13]. More than 40 years later, Shinya Yamanaka discovered how intact mature cells in mice could be reprogrammed to become PSCs, able to develop into all types of cells in the body, by introducing only a few genes [14-16].

The ESCs are present in the blastocyst and can be differentiated into all types of cells, and are therefore pluripotent. Various postnatal tissues present ASCs for their normal renewal as well as regeneration or injury healing. Recent research in tissue engineering and regenerative medicine has demonstrated that SCs can be widely used in dentistry, more so than synthetic materials because teeth are a rich source of SCs [17]. Mesenchymal stem cells (MSCs) are a type of ASC of great importance in regenerative medicine due to their responsibilities in tissue repair and growth, cell substitution, and wound healing due to physiological or pathological causes. MSCs can be isolated especially from bone marrow and adipose tissue, but also from other various human tissues like the placenta, amniotic fluid, liver, umbilical cord, synovial membrane, skin, muscle, and dental tissues [18].

Different types of SCs obtained from oral and maxillofacial tissues, with similar in vitro properties as bone marrow-derived MSCs, are being defined as multipotent stromal cells. They are able to differentiate into different types of cells like chondrocytes, myocytes, osteoblasts, and adipocytes. Recently, the immunomodulatory properties of MSCs have been reported, which enable their clinical use in the treatment of inflammatory conditions [19]. Considering their location in the oral and maxillofacial region, the ASCs are grouped in two major categories: dental and non-dental [20] (Figure 2).

The easy access, proliferation capacity, and multidirectional in vivo/in vitro differentiation makes orofacial SCs an important source of SCs for use in regenerative dentistry and medicine. Therefore, their potential clinical application in dentistry or other medical fields is diverse.

- Dental pulp stem cells (DPSCs), the first human dental MSCs found inside teeth, are considered a significant source for future regenerative procedures both in dental and general medical applications [21]. DPSCs are isolated from the dental pulp of primary or permanent teeth. Their high capacity for in vitro differentiation includes odontoblast, osteoblast, myoblast, adipocyte, dentin-pulp, cardiomyocyte, neuron-like cell, and hepatocyte-like cells, whereas in vivo, they are limited to only adipocytes, endotheliocytes, and myofibers [8,22,23]. 
- Periodontal ligament stem cells (PDLSCs), present on alveolar bone surfaces and the root, play a specific role in cementum or periodontal ligament (PDL) tissue regeneration. They are capable of giving rise to mesenchymal cell lineages to produce in vitro osteoblast-like cells, cementum tissue, Sharpey's fibers, adipocytes, and collagen-forming cells $[17,24]$.

- Stem cells from apical papilla (SCAPs) are mesenchymal formations. They can be found within immature roots and isolated from the immature permanent apical papilla. SCAPs are good sources of and cause apexogenesis. They have a higher capacity to proliferate than DPSCs, being the first option for tissue regeneration. SCAPs represent a promising source of SCs, as they can differentiate into various lineages of cells, such as odontogenic, chondrogenic, osteogenic, adipogenic, neurogenic, and hepatogenic cells [25].

- Dental follicle stem cells (DFCs) are sourced from the dental follicle, which is loose connective tissue surrounding the developing tooth germ [17]. DFCs can differentiate osteoblast, cementoblast, alveolar bone, dentin-like tissues, PDL, cementum, adipocyte, chondrocyte, cardiomyocyte, and neuron-like cell. Their regenerative potential is highlighted by clinical applications in periodontal and neural tissue regeneration, tooth root regeneration, and bone defects $[17,20,26,27]$.

- Tooth germ progenitor cells (TGPCs) are obtained from the dental mesenchyme of the human third molar germ in the late bell stage of tooth development. Studies on TGPCs have demonstrated their high proliferation activity and capacity to differentiation into adipogenic, chondrogenic, osteogenic, odontogenic, and neurogenic tissue [28,29]. In addition, TGPCs can differentiate into hepatocytes in vitro $[25,30]$ and are able to form tube-like structures, possibly evidence of vascularization [31].

- Stem cells of human exfoliated deciduous teeth (SHEDs), obtained from exfoliated deciduous teeth, have higher proliferation capacity than DPSCs and the capability to differentiate into many more different body tissues than other types of SCs, including into adipocytes, osteoblasts, odontoblasts, neural cells, hepatocytes, and endothelial cells. SHEDs have a high proliferation capacity, high multipotency, immunosuppressive ability, and minimal risk of oncogenesis [32]. The major disadvantage of SHEDs is that an incomplete pulp-dentin-like complex is formed in vivo [17].

- Alveolar bone-derived mesenchymal stem cells (ABMSCs), isolated from the human alveolar bone, are a more convenient tissue source of MSCs and have the ability of multipotent differentiation into osteoblasts, adipocytes, and chondroblasts. In addition, they can induce ectopic bone formation in vivo [19].

- Salivary gland-derived stem cells (SGDSCs) are isolated from human salivary glands. The regeneration of salivary gland function with SGDSCs is still being investigated, though certain studies have already concluded that progenitor cells isolated from stromal tissue can be guided to differentiate into osteoblasts, chondrocytes, and adipocytes [33].

- Oral mucosa-derived mesenchymal stem cells (OMSCs), include oral epithelial stem cells (OESCs), gingiva-derived mesenchymal stem cells (GMSCs), and periosteum-derived stem cells (PSCs). SCs within the mucosa lining the oral cavity can be isolated from normal or inflamed gingiva, from attached and free gingiva, and from hyperplastic gingiva. OMSCs can differentiate into different mesenchymal lineages and have immunomodulatory properties [33]. 


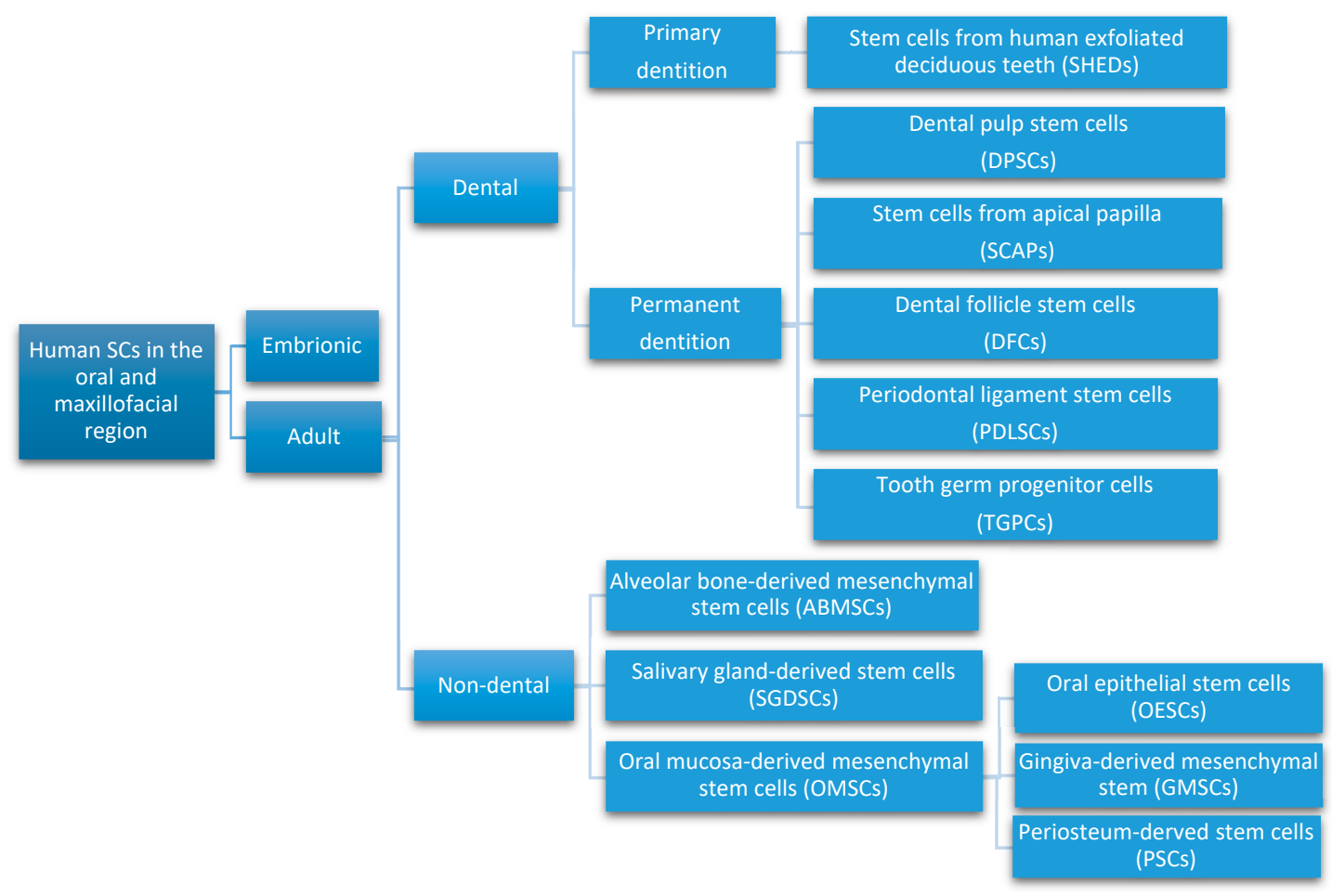

Figure 2. Types of human SCs in the oral and maxillofacial region.

\subsection{Biomaterials and Scaffolds for Oral Tissue Engineering}

In dental tissue regeneration, scaffolds and biomaterials are essential elements. They are used as attachment sites for regenerative cells from the surrounding tissues, as a template for tissue regeneration, as a source of implantable odontogenic cells with the capability to differentiate required cell type, and as bioactive molecules, especially growth factors that intensify the regenerative capability $[34,35]$.

Biomaterials, natural or synthetic, alive or lifeless, are being defined as materials that interact with biological systems. They are often used in medical applications to augment or replace a natural function. Based on their biocompatibility, biomaterials are classified as bioactive, biotolerant, biodegradable, and bioinert [36].

Bioactive materials, by stimulating the biological response, may lead to osteogenesis by making strong chemical bonds. They are being classified into osteoconductive (hydroxyapatite and $\beta$-tricalcium phosphate), which stimulate bone growth along the surface, and osteoproductive (bioactive glasses), which are capable of stimulating the growth of new bone away from the bone/implant interface [36].

Biotolerant materials (polymers and most metals) are being well accepted by the host, but separated from the host tissue by the formation of a fibrous tissue, which is induced by the release of ions, corrosion products, and chemical compounds from the implant.

Biodegradable materials (polymers, such as polyglycolic and polylactic acids, and their co-polymers [37], ceramics as calcium phosphates [38], and magnesium) as biodegradable metal dissolve in contact with body fluids, the dissolution products being eliminated via the kidneys, without noticeable effects to the host. Biodegradable materials are used commonly used for surgical sutures, tissues in growth materials, and controlled drug release [36].

Bioinert materials (titanium and its alloys) are stable in the human body, and do not react with body fluids or tissues. Generally, bioinert materials are encapsulated by fibrous tissues, similar to biotolerant materials; however, in certain situations, they can develop structural and functional connection with the adjacent bone [39].

The most common approach in tissue engineering involves seeding cells onto a biomaterial matrix using a scaffold. 
A wide variety of biomaterials, such as natural organic, synthetic organic, or even inorganic materials, is used for regeneration in oral and maxillofacial area, each of them having advantages and disadvantages. The natural organic materials include peptides (collagen or gelatin) and polysaccharides (alginate, chitosan, agarose). Frequently used synthetic organic materials include poly(lactic acid) (PLA), poly(caprolactone) (PCL), poly(lactic-co-glycolic acid) (PLGA), and poly(glycolic acid) (PGA) [36].

The most commonly used inorganic materials are bioactive ceramics which include glasses or calcium phosphates (hydroxyapatite, $\beta$-tricalciumphosphate), which have been extensively studied as bone replacement materials, and cementitious systems of calcium phosphate or calcium silicate [40].

Bioactive ceramics are strongly chemically bonded with bone tissues via chemical reactions [40]. Hydroxyapatite (HA), bioactive and non-degradable, is characterized by chemical and structural similarity to bone minerals. $\beta$-tricalcium phosphate also has a chemical composition similar to bone, and has higher in vivo rates of biodegradation compared to hydroxyapatite. The degradable bioactive ceramics are characterized by gradually degradation, in order to assist as scaffolds or replace the host tissue [40].

Polymers have been widely studied for medical applications, including bone tissue engineering [41]. From a biomedical perspective, polymers and co-polymers can be divided into two classes, biodegradable and biotolerant.

Biodegradable polymers, synthetic and natural, are suitable for additive manufacturing of scaffolds for tissue engineering [42]. The degradation of polymers, enzymatical or hydrolytical, is of most importance for this application. Natural polymers (chitosan, alginate, collagen, gelatin), frequently used as bioinks, are subject to enzymatic degradation, due to the microorganisms present in the biological environment [43].

The rate of enzymatic degradation varies upon the availability and concentration of respective enzymes. Hydrolytical degradation is related to synthetic polymers, and involves cleavage of hydrolytically sensitive bonds in the polymer, with consequent bulk or surface erosion, important in determining the best choice for a certain application [44].

Surface erosion offers several benefits for bone tissue engineering, such as retention of mechanical integrity, enhanced bone ingrowth, and ensures that the scaffold is gradually replaced by bone tissue [45].

PGA, PLA, PLGA, and PCL are hydrolytically degradable polymers [46].

PGA is usually used for short-term tissue engineering scaffolds and as fillers, because its rapid degradation and insolubility [47].

PLA, when mixed with glycolic acid, forms the copolymer PLGA, which is one of the most investigated degradable polymer for biomedical applications. Its great cell adhesion and proliferation properties recommend it as an excellent choice for tissue engineering [48,49].

Polymers can be processed to offer porous structures capable of facilitating the transportation of growth factors (nutrients as well as anabolites and catabolites) and are of interest due to their controllable degradation [41].

Recently, composite materials are being increasingly used due to their properties that result from the combination of both organic and inorganic elements. The most recent studies on this subject have considered the targeted and scaffold-assisted regeneration of enamel, dentin, and cementum [35].

An essential factor in tissue engineering is the scaffold. It offers a surface upon which cells adhere, multiply, thrive, and produce the ECM of proteins and saccharides that create the living tissue. Cells are expanded in culture and then transferred to the scaffold. The composition of the scaffold material and its internal architecture (dimensions of the struts, walls, pores, or channels) modulate and control the biological properties of the cells [50].

Generally, the scaffold materials must be biocompatible, biodegradable, porous, and without toxic metabolites. In particular, in dental regeneration, biomaterials must be suitable for the specific environment characteristics of the oral cavity considering $\mathrm{pH}$, temperature, the presence of 
microorganisms, and the effect of mastication forces. To achieve these properties, most designed scaffolds deliberately mimic the structure of the natural ECM [36].

The number of suitable materials for fabricating scaffolds is limited by their biocompatibility, as they must accommodate the encapsulated cells and the recipient's body. Because of poor biocompatibility, scaffolds can generate aggressive in vivo foreign-body reactions, necessitating the development of smart immunomodulatory biomaterials that ensure the tolerance of foreign scaffolds by the host or regulating the immunological microenvironments to ensure cell survival [49].

The behavior of cells after adhesion to the scaffold is affected by pore shape, volume, size, and geometry. Different pore sizes can affect the extracellular matrix. Porosity and interconnectivity are important for the ingrowth of surrounding tissues [51]. Open and interconnected pores allow oxygen and nutrients to be transported into the interior and eliminate the waste generated by cellular metabolism [52].

A wide range of advanced smart biomaterials and constructs with intelligent properties and functions have recently been developed to improve tissue repair and regeneration processes [5]. Smart scaffolds incorporate bioactive molecules and nanoparticles and their physical and chemical properties are tailored as needed [53,54]. Their role is to improve the interactions with cells by enhancing the osteogenic differentiation for bone repair and to generate a better response to the surrounding environment [55] and include [5]:

a. Smart scaffold constructs with stem cells for bone tissue engineering

- Biomimetic and bionic smart scaffolds, such as biomimetic porous PLGA microspheres coupled with peptides prepared to mimic the composition and structure of natural tissues [56].

- Immune-sensitive smart scaffolds, such as an amino-functionalized bioactive glass scaffold developed to investigate its effects on MSCs, bone marrow, and macrophages [57]. $\beta$-tricalcium phosphate has been used to coat Mg scaffolds, and modulate its detrimental osteoimmunomodulatory properties [58].

- Shape-memory smart scaffolds, such as bone morphogenetic protein2-loaded shape-memory porous nanocomposite scaffold, consisting of chemically crosslinked poly( $\varepsilon$-caprolactone) and hydroxyapatite nanoparticles, used for the repair of bone defects, displayed shape-memory recovery [59].

- Electromechanical-stimulus smart scaffolds. Piezoelectric poly(vinylidene fluoride-trifluoroethylene) (PVDF-TrFE) was fabricated into flexible, 3D fibrous scaffolds. These have the ability to stimulate MSCs differentiation and tissue formation [60]. An electrospun PVDF-TrFE fiber scaffold containing zinc oxide nanoparticles was able to promote the adhesion and proliferation of human MSCs and also enhance the blood vessel formation [61].

b. Smart drug delivery for bone tissue engineering

- Stimuli-responsiveness tunable drug delivery systems. These materials can change their properties as response to an endogenous and/or exogenous stimulus; thus, delivering the required amount of drug on-demand [62]. Polymers and hydrogels are used [63,64]. A highly porous, $\mathrm{pH}$-responsive bacterial cellulose-g-poly(acrylic acidco-acrylamide) hydrogel was developed as an oral controlled-release drug delivery carrier [64]. A poly(ethylene glycol) hydrogel, loaded with drugs by $\beta$-eliminative linkers, demonstrated tunable capability in drug release [65]. Farnesol-loaded nanoparticles, composed of 2-(dimethylamino)ethyl methacrylate, butyl methacrylate, and 2-propylacrylic acid are characterized by a $\mathrm{pH}$-responsive drug release capability [66]. 
- Smart multifunctional nanoparticle-based drug delivery systems: mesoporous silica nanoparticles, bone-forming peptide-1-laden MSNs encapsulated into arginine-glycineaspartic acid-treated alginate hydrogel [67].

- Biomimetic drug delivery systems: hydrogels, liposomes, micelles, dendrimers, polymeric carriers, and nanostructures [68,69].

c. Smart biomaterials and constructs to promote dental and periodontal regeneration, such as bilayered PLGA/calcium phosphate constructs [70] and tri-layered nanocomposite hydrogel scaffold: alveolar bone phase of chitin-PLGA/nanobioactive glass ceramic (nBGC)/platelet-rich plasma derived growth factors, PDL phase of chitin-PLGA/fibroblast growth factor, and cementum phase of chitin-PLGA/nBGC/cementum protein 1 [71].

d. Smart dental resins that respond to $\mathrm{pH}$ to protect tooth structures, such as dental composites containing nanoparticles of amorphous calcium phosphate and tetracalcium phosphate [72].

e. Smart $\mathrm{pH}$-sensitive materials selectively inhibit acid-producing bacteria, and include cationic poly(phenylene vinylene) derivative, $\mathrm{pH}$-sensitive quaternary pyridinium salts, for which the antibacterial potency can be controlled by varying the $\mathrm{pH}[73,74]$.

f. Smart resins that modulate the oral biofilm composition: quaternary ammonium methacrylates such as 12-methacryloyloxy dodecyl pyridinium bromide, methacryloxylethyl cetyl dimethyl ammonium chloride, quaternary ammonium polyethylenimine, and dimethylaminododecyl methacrylate $[75,76]$.

g. Smart tailoring of alkyl chain length in quaternary ammonium methacrylates to avoid drug resistance $[5,77]$.

SCs are capable to differentiate into various cell phenotypes based on their lineage and exposure to different environmental stimuli, such as ECM, growth factors, hypoxia, etc. [78]. The growth factor, usually a secreted protein or a steroid hormone, stimulates wound healing, cell proliferation, and occasionally cellular differentiation, and regulates various cellular processes. Cytokines and hormones bind to specific receptors on the surface of the target cells. Growth factors typically act as signaling molecules between cells, thus promoting cell differentiation and maturation $[79,80]$.

The authors experience related to the subject includes tetracycline loaded collagencarboxymethylcellulose/hydroxyapatite ternary composite materials [81], antiseptic composite materials containing silver nanoparticles, based on collagen, hydroxyapatite, and collagen/ hydroxyapatite [82], collagen matrices with lidocaine [83], bone regeneration using synthetic HA, with high porosity and surface area for osteointegration [84-87].

\subsection{Additive Manufacturing Technologies for Oral Tissue Engineering}

Continuous development of manufacturing technologies enable printing of biofunctional scaffolds similar to the ECM, acting as a microenvironment for cell adhesion, proliferation, and differentiation [88,89].

The additive manufacturing (3D printing) of biomaterials offers promising future perspectives for the field of biomedical engineering [90], especially in regard to patient-specific clinical applications.

Additive manufacturing techniques for medical and tissue engineering purposes can be classified as: techniques which involve printing of live cells along with other materials (3D bioprinting) [91], and non-cellular fabrication techniques.

3D bioprinting, based on the layer-by-layer precise positioning of biological constituents, biochemicals and living cells, facilitates on-demand "printing" of cells, tissues and organs [92,93] for regenerative medicine purposes [94]. Utilizing diverse bioprinting techniques, tissue-engineered constructs can be tailored to obtain desired structures and properties $[95,96]$.

Inkjet bioprinting functions by depositing small ink droplets into a predetermined location. It can be driven by thermal or piezoelectric actuation [97]. In thermal technology, heat-generated, the inflated bubble forces the ink out of the narrow nozzle and onto the substrates. In piezoelectric technology, drops are generated in absence of heat, by the transient pressure from the piezoelectric 
actuator. The droplets remain directional with regular and equal size [98], but, if used too frequently, this technology can cause damage to the cell membrane and cell lysis.

Laser-based bioprinting consists of a pulsed laser source, a ribbon, and a receiving substrate. The biological material, in liquid form, is irradiated by the laser, evaporates, and reaches the receiving substrate as droplets. Laser-based bioprinting enables high-resolution printing of biological material such as cells, DNA, and peptides [99]. Its drawback is that the use of the pulsed laser source may result in compromised cell viability [100].

Stereolithography bioprinting uses a photo-crosslinking light source to obtain desired patterns. It is highly tunable and prints in a layer-by-layer manner, the bioink from the reservoir being transferred to a movable platform [101].

Pressure-assisted bioprinting uses biomaterials in form of solutions, pastes or dispersions. The material, in form of a filament, is extruded by pressure through a microneedle or a microscale nozzle orifice [102].

Bioink printability has an important role in the fabrication process $[103,104]$. Besides being biocompatible and biodegradable, bioinks should be deformable and flowable [102]. After printing, the bioink should be stable in order to maintain shape and architecture of the design model [105].

The components of the bioink are polymers, ceramics, hydrogels, and composites, currently used in tissue engineering [106]. Hydrogel inks are much more attractive as bioprinting materials, compared to polymers and ceramics have received much more attention, and novel ink formulations have been designed [107]. Complex, functional, and biocompatible hydrogels can be fabricated using bioprinting technology. Adding different amounts of HA was attempted to a tunable alginate-gelatin hydrogel composite [108], human MSCs being subsequently mixed. Adding HA to the hydrogel resulted in enhanced mechanical properties, recommending it hard tissue reconstruction. No reduction in cell viability was detected [109]. The freeform reversible embedding of suspended hydrogels, a 3D bioprinting technique which deposits and crosslinks different kind of hydrogel inks, has been proven successfully [110].

An important concern when printing SCs-including ESCs, MSCs, and ASCs-is that their activity, including proliferation and pluripotency, may change during the process [111,112]. MSCs were successfully laser-printed for the construction of scaffold-free autologous grafts. The seed cells survived and maintained their ability to proliferate and continue differentiating into the osteogenic lineage [113].

Non-cellular additive manufacturing techniques include (Table 1):

The powder bed fusion methods which use either electron beam or laser to selectively consolidate material powder. The techniques involve spreading material powder over the previous layers, melting and fusing it [114].

The binder jetting technique is similar to the powder bed fusion technique and utilizes material powder that is spread over previous layers. Unlike powder bed fusion, this technique uses a binder as an adhesive for its consolidation $[115,116]$.

The fused deposition modeling technique is based on the extrusion of heated polymer wires through a nozzle tip. The polymer rods are deposited and arranged in a layer by layer fashion [117].

The material jetting technique uses a liquid photopolymer resin that is light-cured. Similar to the material extrusion technique, the material is deposited from a nozzle and cured, defining a cross section. Individual cross sections are consolidated in a layer by layer fashion as the building platform moves in the vertical direction [118].

The vat polymerization technique uses a vat of liquid photopolymer resin, deposited in a layer by layer fashion. The build platform moves (depending on the position of the light source) to create additional layers on top of the previous [119].

These techniques all have their pros and cons and can process different types of biomaterials [120] (Table 1). 
Table 1. Additive manufacturing methods of biomaterials for oral tissue engineering.

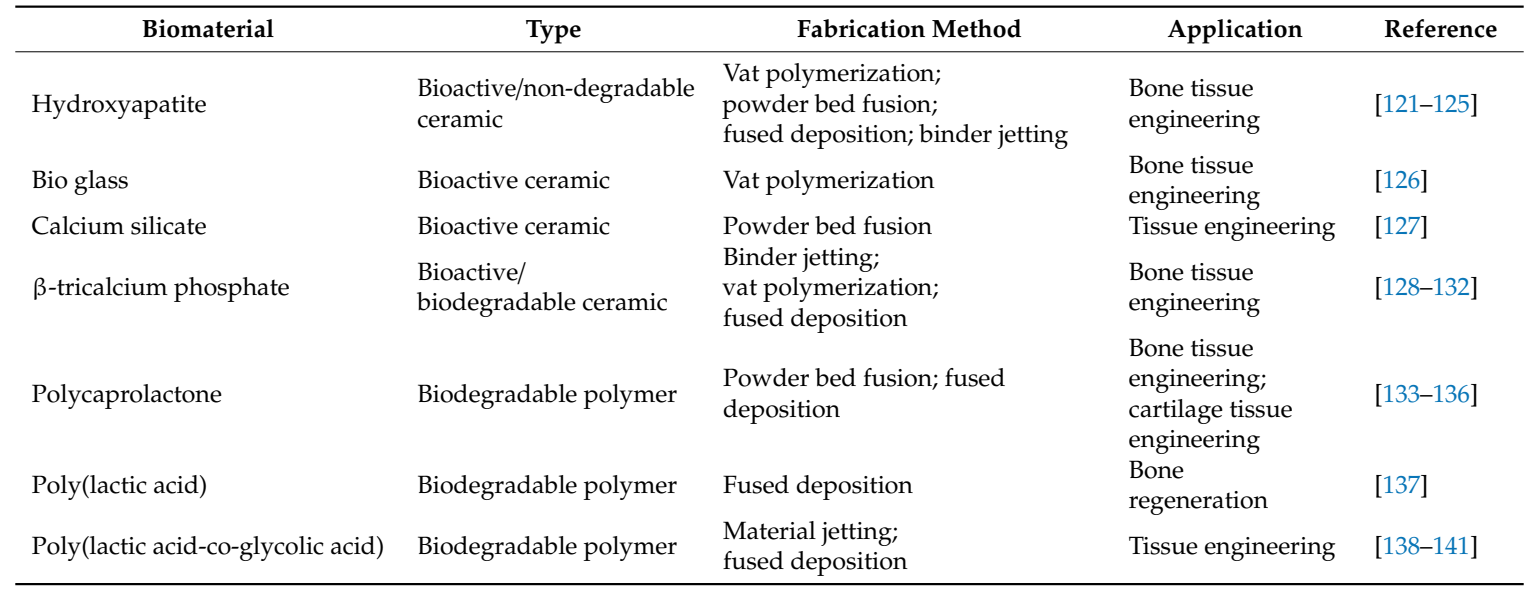

\section{Regenerative Therapies in Dentistry-Potential Clinical Applications of Dental Stem Cells}

Four main groups of defects in the oral area represent the main targets of soft or hard tissue regeneration: maxillofacial defects, periodontal diseases (gingiva inflammation, PDL, alveolar bone, and cementum loss), dental pulpal diseases, and hard tissue defects of the tooth [142]. In addition, tissue engineering and regeneration are oriented toward several applications of dental SCs with the aim of accelerating the healing of oral injury without scar formation [143]. Table 2 lists the potential clinical applications of dental SCs in regenerative dentistry.

Table 2. Potential clinical applications of dental SCs in regenerative dentistry.

\begin{tabular}{|c|c|c|}
\hline Type of SCs & Regenerative Dental Applications & References \\
\hline DPSCs & $\begin{array}{l}\text { Mandibular bone defects regeneration, scaffold-based dentin-pulp } \\
\text { repair, dentin-pulp tissue regeneration with inflamed pulp, periodontal } \\
\text { regeneration, neural tissue regeneration, muscle regeneration, } \\
\text { angiogenesis induction, craniofacial skeletal repair }\end{array}$ & $\begin{array}{l}\text { Zhou et al. [11] } \\
\text { Zakrzewski et al. [17] } \\
\text { Berebichez-Fridman et al. [18] } \\
\text { Hollands et al. [22] } \\
\text { Tsutsui [23] } \\
\text { Sharpe [24] } \\
\text { Khazaei et al. [28] } \\
\text { Chalisserry et al. [30] } \\
\text { Somani et al. [31] } \\
\text { Yang et al. [142] } \\
\text { Chatzistavrou et al. [144] } \\
\text { Bakopoulou et al. [145] } \\
\text { Tatullo et al. [146] } \\
\text { Potdar et al. [147] } \\
\text { Davila et al. [148] } \\
\text { Gronthos et al. [149] } \\
\text { Beltrão-Braga et al. [150] } \\
\text { Verma et al. [151] } \\
\text { Almushayt et al. [152] } \\
\text { Yoshida et al. [153] } \\
\text { Aydin et al. [154] } \\
\text { Graziano et al. [155] }\end{array}$ \\
\hline PDLSCs & $\begin{array}{l}\text { Tooth root regeneration, periodontal tissue regeneration (cementum, } \\
\text { PDL), bone regeneration }\end{array}$ & $\begin{array}{l}\text { Zhou et al. [11] } \\
\text { Zakrzewski et al. [17] } \\
\text { Liu et al. [20] } \\
\text { Somani et al. [31] } \\
\text { Verma et al. [151] } \\
\text { Aydin et al. [154] } \\
\text { Kitagaki et al. [156] } \\
\text { Hynes et al. [157] } \\
\text { Han et al. [158] } \\
\text { Maeda et al. [159] } \\
\text { Gay et al. [160] } \\
\text { Kim et al. [161] }\end{array}$ \\
\hline
\end{tabular}


Table 2. Cont.

\begin{tabular}{|c|c|c|}
\hline Type of SCs & Regenerative Dental Applications & References \\
\hline SCAPs & $\begin{array}{l}\text { Bone regeneration, tooth root regeneration, dentin-pulp repair, neural } \\
\text { regeneration and repair, periodontal regeneration, angiogenesis, tooth } \\
\text { regeneration }\end{array}$ & $\begin{array}{l}\text { Zhou et al. [11] } \\
\text { Liu et al. [20] } \\
\text { Kang et al. [25] } \\
\text { Khazaei et al. [28] } \\
\text { Somani et al. [31] } \\
\text { Bakopoulou et al. [145] } \\
\text { Verma et al. [151] } \\
\text { Aydin et al. [154] } \\
\text { Schneider et al. [162] } \\
\text { Nada et al. [163] } \\
\text { Miller et al. [164] } \\
\text { Wongwatanasanti et al. [165] }\end{array}$ \\
\hline DFCs & $\begin{array}{l}\text { Bone defects, tooth root regeneration, periodontal tissue regeneration, } \\
\text { neural tissue regeneration, enhancement of bone regeneration on } \\
\text { titanium implant surfaces in humans }\end{array}$ & $\begin{array}{l}\text { Zhou et al. [11] } \\
\text { Zakrzewski et al. [17] } \\
\text { Liu et al. [20] } \\
\text { Chalisserry et al. [30] } \\
\text { Somani et al. [31] } \\
\text { Yang et al. [142] } \\
\text { Verma et al. [151] } \\
\text { Aydin et al. [154] } \\
\text { Zhang et al. [166] } \\
\text { Shoi et al. [167] } \\
\text { Rezai-Rad et al. [168] } \\
\text { Honda et al. [169] }\end{array}$ \\
\hline TGSCs & Bone repair and cartilage regeneration & $\begin{array}{l}\text { Zhou et al. [11] } \\
\text { Chalisserry et al. [30] } \\
\text { Verma et al. [151] } \\
\text { Aydin et al. [154] } \\
\text { Caracappa et al. [170] } \\
\text { Yalvaç et al. [171] } \\
\text { Yalvaç et al. [172] } \\
\text { Doğan et al. [173] }\end{array}$ \\
\hline SHEDs & $\begin{array}{l}\text { Critical-sized craniofacial bone defect regeneration, scaffold-based } \\
\text { dentin-pulp regeneration, neural and blood vessel regeneration, tooth } \\
\text { root regeneration, tubular dentin }\end{array}$ & $\begin{array}{l}\text { Zhou et al. [11] } \\
\text { Liu et al. [20] } \\
\text { Sharpe [24] } \\
\text { Somani et al. [31] } \\
\text { Verma et al. [151] } \\
\text { Aydin et al. [154] } \\
\text { Jeon et al. [174] } \\
\text { Araújo et al. [175] } \\
\text { Ma et al. [176] } \\
\text { Kunimatsu et al. [177] } \\
\text { Ching et al. [178] } \\
\text { Miura et al. [179] } \\
\text { Martinez Saez et al. [180] } \\
\text { Annibali et al. [181] } \\
\text { Arora et al. [182] }\end{array}$ \\
\hline ABMSCs & Bone defects, periodontal regeneration & $\begin{array}{l}\text { Zhou et al. [11] } \\
\text { Liu et al. [20] } \\
\text { Verma et al. [151] } \\
\text { Aydin et al. [154] } \\
\text { Caracappa et al. [170] } \\
\text { Mason et al. [183] } \\
\text { Liu et al. [184] } \\
\text { Pekovits et al. [185] } \\
\text { Matsubara et al. [186] } \\
\text { Park et al. [187] } \\
\text { Lim et al. [188] } \\
\text { Khazaei et al. [189] }\end{array}$ \\
\hline
\end{tabular}


Table 2. Cont.

\begin{tabular}{lll}
\hline Type of SCs & Regenerative Dental Applications & \multicolumn{1}{c}{ References } \\
\hline & & Liu et al. [20] \\
Chalisserry et al. [30] & Grawish [33] \\
Verma et al. [151] & Aydin et al. [154] \\
& & Caracappa et al. [170] \\
GMSCs & Neural regeneration, periodontal regeneration, cartilage, bone, & Zhang et al. [190] \\
& muscle, oral mucositis, & Tomar et al. [191] \\
& improving the regeneration of craniofacial bone & Tang et al. [192] \\
& & Wang et al. [193] \\
& & Marynka-Kalmani et al. [194] \\
\end{tabular}

\subsection{Regenerative Endodontics}

Regenerative endodontic therapy (RET) is defined as "biologically based procedures designed to replace damaged tooth structures, including dentin and root structures, as well as cells of the pulp-dentin complex" [196]. Regenerative endodontics aims to restore normal function of the pulp, by regenerating the dentin-pulp complex damaged by infection, trauma, or developmental anomalies of immature permanent teeth with necrotic pulp. The benefits of regenerative endodontics not only stand in revitalization of the tooth, but also continued root development and, potentially, increasing fracture resistance [197].

Apexification and apexogenesis are clinical procedures closely related to regenerative endodontics [198]. Pulp necrosis in young permanent teeth poses a challenge to clinicians due to the open and underdeveloped apex [199]. The purpose of endodontic treatment, or hermetic sealing of the foramina, can be easily achieved in mature permanent teeth where there is an apical constriction. Because the young permanent teeth do not have an apical constriction, a hermetic seal of the foramina is almost impossible. It traditionally consists of the apexification procedure with calcium hydroxide or a mineral trioxide aggregate (MTA) plug, which stimulates the periapical cells to form a dentin-like substance in the apex region. This process, even if it seals the foramina, does not add to the thickness and strength of the dentin walls, making the root prone to fractures and resulting in a weakened apical barrier [200-202]. Apexogenesis, used in case of injured but not necrotic pulp, leaves the apical one-third of the dental pulp in place, to allow complete formation of the root [198].

The first studies on pulp regeneration were conducted by Nygaard-Otsby et al. [203,204]. Intentionally, overinstrumentation was used to induce bleeding from the periapical tissues into the root canal, followed by a short obturation to allow tissue growth into the canal space. The histological examination of the extracted teeth revealed that fibrous connective tissue and cellular cementum formed in the canal space [203]. Later on, Banchs and Trope [205] proposed a revascularization protocol based on the experiments of Kling et al. [206] on implanted teeth, Hoshino et al. [207] on root canal disinfection, and Nygaard-Otsby et al. [204] on blood clots in the canal space.

Regenerative endodontics originates from the revascularization literature, which focuses only on the delivery of blood into the root canal space. It aims to allow its filling with vital tissue as a result of wound healing, but does not include a source of SCs within the apical tissues, their delivery into root canals, and the intentional release and use of local growth factors embedded into the dentin [208].

The American Association of Endodontists' (AAE) clinical considerations RET define success by three measures [209]: the primary/essential goal, which is the elimination of symptoms and the evidence of bony healing and is the objective of all endodontic treatments; the secondary/desirable goal, which is increased root wall thickness and/or increased root length and, thus, the continuation of root maturation leading to a smaller incidence in root fracture; and the tertiary goal, which is a positive response to vitality testing.

RET represents an extension of root canal therapy, aiming to heal apical periodontitis. Conventional root canal therapy only cleans and fills the pulp chamber with biologically inert material. RET aims to 
replace live tissue in the pulp chamber and regenerate its normal function, by stimulating its regrowth or by inserting bioactive substances in the pulp chamber [210].

Previous studies evaluated combinations of SCs, growth factors, and scaffolds that result in histological regeneration of pulp tissues [211] (Figure 3).

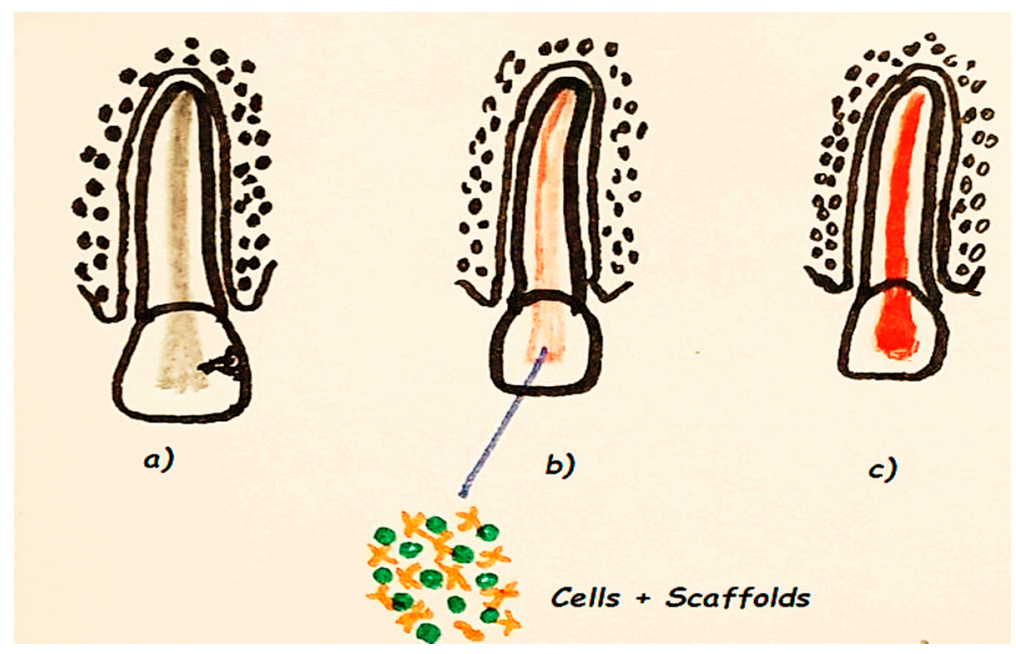

Figure 3. Regeneration of functional pulpal tissue: (a) non-vital pulp, (b) transplantation of stem cells, (c) regenerated pulp.

ASCs, especially MSCs (DPSCs, SCAPs) are used in RET. Lacerating the apical papilla and subsequently delivering a high local concentration of SCs into the root canal space does not necessarily result in their differentiation into cells of the pulp-dentin complex. Growth factors act as important adjuncts in RET. Histologic signs of tissue repair rather than regeneration may be due to lack of control of endogenous growth factors [212].

SCs are capable of differentiating into odontoblasts, pulp fibroblasts, and other niche cells characteristic of dentin-pulp complex. To ensure the success of RET in the adult, exogenously delivered and/or endogenous growth factors must induce the sprouting of neural fibrils and endothelial cells along with other blood vessel resident cells [213].

Regenerative endodontics is based on adequate disinfection of the root canal system, induction of bleeding through overinstrumentation to create a scaffold for stem cells, and coronal sealing of the blood clot with a biocompatible material, such as MTA [214].

However, certain variables related to patient age, apex diameter, canal instrumentation, disinfection, medication, and coronal seal have to be considered when evaluating RET success.

Even though RET has been used on mature teeth, most of the reported cases are on young patients where pulp necrosis has halted the root maturation process. According to Estefans et al. [215] younger age groups are better candidates for revascularization procedures than older age groups.

In immature permanent teeth, apical diameter is of importance for RET. In cases of a preoperative apical diameter wider than $1 \mathrm{~mm}$, greater root maturation was observed [215]. Nevertheless, apical diameters of $0.5-1.0 \mathrm{~mm}$ demonstrated the highest clinical success rate [216]. The pulp tissue regeneration is influenced by the presence of prior infection, which negatively affects the tissue-forming cells as well as SCs in the periapical tissues [217].

The removal of pulp necrotic tissue is vital to the success of pulp regeneration but mechanical removal may be contraindicated because it weakens the already affected dentinal walls [20] and could damage vital tissue remnants in the apical part of the canal $[218,219]$. According to Lin et al. [220] most of the bacteria are hosted in the apical portion and the biofilm formed on the canal walls penetrates the dentinal tubules. They concluded that, to some degree, mechanical debridement might be necessary to disrupt the biofilm for better chances of root maturation to continue [220], as root-canal-irrigating 
solutions and intracanal medicaments are not able to completely eliminate bacteria biofilms in infected root canals during root canal therapy [221,222].

Infection prevents regeneration, repair, and SCs activity, so disinfecting the root canal system is crucial to the success of RET [223]. Strategies for optimal disinfection of the pulp space with minimal disruption of the necessary biological factors from dentin, the progenitor cells in periapical vital tissues, and the vascularity, to promote periapical healing as well as soft and hard tissue development after an infectious process are being currently available [214].

After an infection, new tissues cannot form inside the canal space. Only if osteoblasts, cementoblasts, periodontal ligament cells, and endothelial cells can migrate inside the canal is there a chance of developing new tissues.

The chemicals used to disinfect the root canal system have bacteriostatic or bactericidal properties and should not damage healthy tissues, thus lowering the chances of RET success [214,224].

$\mathrm{NaOCl}$ is a potent antimicrobial agent that effectively dissolves necrotic and organic tissue [225], which is very effective against biofilm $[226,227]$. Based on the cytotoxic effect of $\mathrm{NaOCl}$ on in vitro survival of SCAPs, a concentration of $1.5 \% \mathrm{NaOCl}$ is recommended [58,228]. Other studies [229] reported that the SCAPs survival rate is $74 \%$ after being exposed to $6 \% \mathrm{NaOCl}$ followed by $17 \%$ ethylenediaminetetraacetic acid (EDTA) and $6 \% \mathrm{NaOCl}$ once more. The AAE suggests irrigation with $\mathrm{NaOCl}$ for $5 \mathrm{~min}$ and then with saline or EDTA for $5 \mathrm{~min}$, using a system that lowers the possibility of irrigant extrusion into the periapical space, at about $1 \mathrm{~mm}$ shorter than the working length, to maximize the survival rate of SCAPs [230]. Hence, the $\mathrm{NaOCl}$ concentrations could be adjusted with some precautions and the SCAP survival rate is not significantly affected $[205,218,219,231]$.

EDTA is a chelating agent used to remove smear layer in conventional root canal therapy [232] and to cause the release of growth factors from dentin matrix in RET [233], resulting in dentin demineralization and its exposure to the released growth factors [230,234]. The use of $17 \%$ EDTA resulted in an increased SCAP survival rate as well as partial reversal of the deleterious effects of $\mathrm{NaOCl}$ [229]. EDTA conditioning of dentin promoted the adhesion, migration, and differentiation of DPSCs toward or onto dentin [230]. Therefore, a final rinse with EDTA before creation of a blood clot is advised. Release of growth factors from dentin matrix after EDTA treatment was reported in non-infected root canals $[233,234]$. A residual biofilm may significantly diminish the bioavailability or bioactivity of dentin-matrix-associated growth factors [235]. Dentin-matrix-derived growth factors released after EDTA treatment may signal SCAPs to differentiate into odontoblast-like cells [236].

The use of chlorhexidine ( $\mathrm{CHX)}$ as canal disinfectant is based on its antimicrobial activity that extends by interacting with the dentin. $\mathrm{CHX}$ cannot dissolve tissues and it is not advisable to use it as the only irrigation solution [225,237]. Haapasalo et al. [225] suggested that the initial $\mathrm{NaOCl}$ irrigation should be followed by sterile saline and $2 \% \mathrm{CHX}$, the role of saline solution being to stop any interactions between $\mathrm{NaOCl}$ and $\mathrm{CHX}$.

Intracanal medication between endodontic treatment sessions assists with the control of microbial infection by using different substances as calcium-hydroxide-based and polyantibiotic pastes. It aims to stop microbial proliferation in the root canal system and combine antibacterial and anti-inflammatory properties with the capacity to induce mineralized tissue formation, having beneficial effects on repairing the apical tissues [238].

Traumatized immature permanent teeth with infected necrotic pulp have similar microbial ecology as mature permanent teeth [239], including biofilms formation on the radicular canal walls and bacteria penetration into the canal dentinal tubules [240].

Antibiotics have been used as intracanal medication in root canal treatment since the 1950s [241], but local application of antibiotics in endodontics has been restricted because of the risks of adverse effects. The interest in using a combination of antibiotics has reemerged with the introduction of the triple antibiotic paste (TAP) [238]. The ciprofloxacin, metronidazole, and minocycline TAP [207] is sufficiently potent to eradicate bacteria from the root canal. A double antibiotic paste of metronidazole and ciprofloxacin [218] has also proven its efficacy. Studies have shown that TAP is biocompatible [239] 
but, unfortunately, antimicrobial combinations can prove to be cytotoxic and increase the risk of adverse effects, and bacterial resistance $[239,240]$. Augmentin has been shown to kill $100 \%$ of the microorganisms isolated from the infected root canal associated with in vitro apical abscess [241]. It acts by inhibiting bacterial cell wall synthesis, only affecting bacterial cells and not human cells, as the latter do not have a cell wall.

Calcium hydroxide is considered the first choice for intracanal medication in RET. It offers good antimicrobial properties, anti-inflammatory activity, consequent stimulation of apical repair, and participation in mineralized tissue formation, inducing differentiation of periodontal ligament cementoblasts and cementogenesis by increasing extracellular calcium levels and tissue compatibility [242]. According to prior studies, dentin is capable of inactivating root canal medication [243,244], thereby limiting the efficacy of calcium hydroxide as an intracanal dressing [245]. Because of its high $\mathrm{pH}$, it can damage the cells that have regenerative capacity [246]. When treated with calcium hydroxide rather than TAP, human apical cells attach to the root dentin walls at a higher rate [247].

Various other materials have been used to induce apexification, such as tricalcium phosphate [248], collagen calcium phosphate [248], osteogenic protein-1 [246], and MTA [246] without affecting root elongation or maturation [246]. The apical plug of MTA and gutta-percha filling has several advantages over calcium hydroxide-induced apexification. MTA is biocompatible, has osteoinductive properties, sets in the presence of moisture, and the treatment can be completed in a single appointment, though it does not strengthen the remaining tooth structure [249].

After disinfection of the canal and resolution of symptoms, RET usually involves lacerating of the periapical tissues to initiate bleeding or the use of platelet-rich plasma (PRP) [250], platelet-rich fibrin (PRF) unmineralized tissue matrices, and synthetic materials like polyglycol or collagen [251,252].

Studies have shown that inducing bleeding into the disinfected canal is an important step in regenerative procedures; a stable blood clot $(\mathrm{BC})$ not only serves as a scaffold but triggers significant accumulation of undifferentiated STCs into the canal space [253] and stimulates cell growth and the differentiation of STCs into odontoblast-like cells [228,253-255].

A common problem is the failure to induce apical bleeding or to achieve adequate blood volume in the canal $[202,256,257]$. In pluri-rooted teeth, this can be achieved by transferring some blood from other roots, but this approach cannot be used for single-rooted teeth. Because of this, researchers have searched for other scaffold options. PRP, PRF, and platelet pellet (PP) are options that have shown promising clinical and radiological results [256]. Cehreli et al. [257] reported the clinical outcomes of PRP, PRF, and PP used in the presence or absence of a BC. PRP, PRF, and PP, even if more expensive than the $\mathrm{BC}$ method, can offer a longer exposure to growth factors, and are possibly better scaffolds since they also eliminate the progressing obliteration of the root, a problem found with the BC method [257].

After the scaffold has set and stability has been confirmed, a coronal seal should be placed over the blood clot to serve as an internal matrix. The AAE recommends an MTA layer of approximately $3 \mathrm{~mm}$, followed by a 3-4 mm layer of glass ionomer and a layer of reinforced composite resin [209]. The MTA, which hardens in wet conditions, acts like an antibacterial barrier, but is also associated with teeth discoloration. An alternative to MTA, such as bioceramics and tricalcium silicate cements, should be used in teeth where there are aesthetic concerns [209].

The true success of RET is being difficult to evaluate. Regardless of the presence or absence of an intracanal BC, the concentration of irrigating solution, or type of intracanal medication used, different treatment protocols were able to eliminate clinical symptoms and signs of apical periodontitis. Its potential to promote thickening of the canal walls and/or continued root development is, unfortunately, not yet predictable [224].

\subsection{Regenerative Periodontics}

Considered a distinctive tissue structure, periodontal tissue consists of a three-dimensional complex of alveolar bone, PDL, and cementum. The incidence of periodontal disease, the main cause 
of tooth loss, is increasing among the population, affecting about $20-50 \%$ of the global population without being influenced by age or sex [258-261].

It has a microbial cause and, in most cases, results in irreversible destructive phenomena. Chronic inflammation severely affects the periodontium, leading to the resorption of the alveolar bone, a pathological phenomenon that cannot be stopped by natural processes $[257,262]$.

Nonsurgical periodontal therapies, such as scaling and root planning, represent the first choice methods in preventing disease progression in its first stages, but the removal of pathogens and necrotic tissues provide only partial, local regeneration of the periodontal tissue. Surgery, needed in the advanced stages, or other currently common periodontal therapies, such as growth factors [263] and grafts, could be replaced by the use of SCs as a successful method for treating periodontal diseases due to the existence of SCs in the PDL [264,265].

Since 2004, when PDLSCs were first identified and considered for periodontal tissue regeneration, many other types of stem cells have demonstrated their capacity to form periodontal tissues under certain conditions (Table 2). SC usage has become increasingly relevant in the last decade in the search for an effective solution for periodontitis treatment, despite the fact that regeneration of periodontal tissues is one of the most complex processes in the human body [266]. Thus, aiming high, the target of regenerative dentistry is to develop effective therapies and techniques to treat periodontal diseases using applied tissue engineering and regeneration on the lost or affected support tissue of the periodontium: alveolar bone, periodontal ligament, and cementum [266].

Two major strategies for periodontal regeneration have been outlined: guided tissue regeneration (GTR) and tissue engineering [267]. GTR, a regenerative surgical technique, has been extensively used for periodontium regeneration in recent decades. It aims to prevent apical migration of the epithelium in the bone defect by placing a membrane at the root surface [268,269].

Two types of barrier membranes are used in GTR: non-absorbable and absorbable membranes. The use of the non-absorbable membranes, such as cellulose acetate filters (Millipore filters), rubber dam, specifically processed expanded polytetrafluoroethylene and dense polytetrafluoroethylene has a high risk of infection because a second surgery is required to remove them [270]. Resorbable membranes-such as allogenic soft tissues, freeze-dried skin, freeze-dried duramater, and reconstituted collagen membranes, have been introduced later on—changing GTR into a single-step procedure [270]. The goal of the membrane is to prevent contact between the gingival tissue and the surface of the root, preventing gum growth in the bone space, thereby selectively guiding cells derived from the periodontal tissue onto the root surface. Thus, the periodontal tissue can be regenerated. In practice, a small piece of tissue-like material is inserted between the gingival tissue and the bone [267].

Periodontal therapy with SCs has been considered in studies performed on animals, which have reported an effective contribution to the regeneration process of the SCs implanted into periodontal defects [271]. Periodontal tissue regeneration must be viewed as an integrated healing process-a result of the coordinated interaction between stem cells, biomaterials, growth factors, and the particularities of the patient's immune system (Figure 4). In periodontal regeneration, the tissue engineering strategy may take one of two approaches: scaffold-free or scaffold-based [271]. The scaffold-free approach uses cells or cell aggregates transplanted onto the wound area with no carrier cell. Clinical studies reported that PDLSCs and DPSCs have the potential to form periodontal tissues, but problems occur with cell diffusion out of the defect zone. It has been proven to be a non-relevant regeneration strategy because of the low cell survival rate after transplantation [272]. The cell sheet technique has been developed as a scaffold-free strategy for cell delivery and has been tried in various tissue regenerations, including for periodontal tissue. Cell sheet engineering aims to prevent ECM degradation by isolating cells using enzymes and completely retaining them to ensure normal cell function. Cell sheet engineering can prevent cell migration, but only simple-structured tissues can be regenerated [272]. In conclusion, scaffold-free techniques are not suitable for the complex structure of the periodontium. 


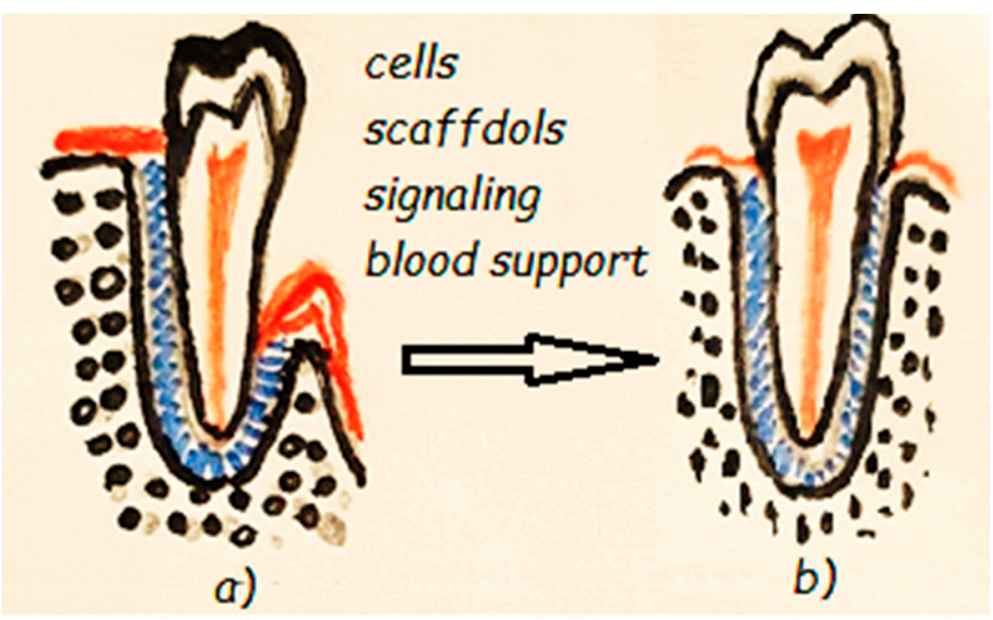

Figure 4. Periodontal tissue regeneration: (a) diseased periodontium, (b) regenerated periodontium.

For the periodontal ligament, cementum, and alveolar bone complex structure regeneration, the scaffold-based approach is more suitable [273].

Multiphasic scaffolds, with distinctive particularities of each layer both in architecture and chemical/biochemical composition, are required to imitate the complex structure of the periodontium. Additionally, the ECM contributes a 3D substructure for cell adhesion and movement, and contains growth factors facilitating the signal delivery needed for morphogenesis and differentiation. PDLSCs sheets demonstrated the potential of periodontal tissue regeneration in experimental deficiencies in rats, dogs, and pigs [274].

Raju et al. reported successful three-dimensional tissue regeneration of a large-scale tissue injury using bioengineered tissue to simulate the anatomical structure in which two types of cells were used for cell sheet fabrication: rat PDL cells extracted from molars and osteoblast-like cells [275]. Periodontal regeneration with autologous periodontal-ligament-derived cell sheets combined with $\beta$-tricalcium phosphate bone was reported as safe and efficacious in a study by Iwata et al. [276].

Biomaterials and controlled drug delivery for periodontal regeneration involve the use of inorganic, polymeric, or composite biomaterials. For bone and cementum repair/regeneration, inorganic biomaterials are the material of choice due to their similarities in composition and mechanical properties. For PDL regeneration, polymeric biomaterials are appropriate. By combining inorganic and polymeric biomaterials, biomimetic scaffolds for bone and cementum regeneration can be fabricated [277].

Thus, bioinspired innovative materials are needed to mimic the complex structure of periodontal tissues at the micro- and nanolevel because, at present, functional periodontal tissue regeneration has yet not been achieved. Many studies with the objective of regenerating the periodontal tissues highlighted that the actual biomaterials cannot exactly mimic the natural architecture of periodontal tissues, so the connections between their components, cementum-PDL-alveolar bone, remain unstable and cannot support teeth or bear occlusal force [278].

For periodontal tissue regeneration, to ensure an ECM-like microenvironment, biomimetic nanofibrous and multilayer scaffolds have been developed. In a recent review, Liang et al. focused on the relevance of advanced bioinspired scaffolding biomaterials and the temporospatial control of multidrug delivery in the regeneration of the cementum-periodontal ligament-alveolar bone complex [267]. A systematic review by Liu et al. [279] presents the newest regeneration developments in the case of all three types of periodontal tissues and for simultaneous regeneration the entire periodontal complex using stem cells, 3D-printing, gene therapy, and layered biostructures.

\subsection{Regenerative Oral and Maxillofacial Surgery}

Oral and maxillofacial surgeries play important roles in the treatment of traumatic and degenerative disease with tissue loss. The techniques used have been improved over time, from using growth 
factors and platelet concentrates to biomaterial scaffolds and autologous tissues and, currently, SCs in regenerative dentistry. In oral and maxillofacial surgery, tissue engineering and regeneration are the approaches currently available for achieving the goals of reconstruction procedures [280].

In maxillofacial reconstruction, surgeons have two main objectives: to provide the anatomic form and the function of the oromaxillofacial area. Because the facial skeleton has a complex structure, reconstruction should restore the volume, shape, bone continuity, and symmetry of the skeletal bone. Because the numerous soft and hard tissues that form this area provide important functions such as articulation, facial expressions, mastication, swallowing, and breathing, the reconstruction must restore, maintain, and stabilize these tissue functions. In addition, the reconstruction must be performed not only for reconstructive goals but also for aesthetic goals. Hence, different types of tissues must be reconstructed layer by layer [281].

Oral and maxillofacial surgery can use MSCs from the oral cavity, which are an important and easily accessible source to the surgeon. Several maxillofacial bone defects can be approached using bone tissue regeneration. Soft tissue, such as skin and oral mucosa, can also be regenerated [282]. Cartilage regeneration, salivary gland regeneration, fat, muscle, blood vessels, and nerve regeneration represent other applications of tissue engineering in oral and maxillofacial surgery $[2,278]$. Recent studies highlight the possibility of using GMSCs as the cellular components for 3D bioprinting of scaffold-free nerve constructs needed for peripheral nerve repair and regeneration [283] or for treating gingival defects [284].

\subsubsection{Bone Regeneration}

Substantial bone defects of the maxilla and mandible, in need of surgery, originate from congenital abnormalities, accidental traumatic injuries, tooth extraction, surgical resection of benign or malign tumors, and infections. The most challenging situation for the maxillofacial surgeon is the restoration of large bony defects due to trauma or post-resection.

In the standard reconstruction of maxillofacial bone defects, autologous grafting is still the gold standard technique, even if it presents many disadvantages [285].

A perfect technique and material for bone reconstruction has not yet been found, even if many clinical approaches have been attempted in recent years. Bone tissue engineering techniques provide a solution for reconstructing large size bone defects in the oral and maxillofacial region using autologous bone grafts, conditioned by adequate vascularization. Wu et al. [286] reviewed new strategies for improving vascularization of engineered bone tissue and their possible feasible clinical applications using SCs, mainly MSCs originating from bone marrow or adipose tissue as well from dental tissues. MSCs are a key element in bone regeneration due to their capacity to induce bone regeneration by mimicking biological processes [287].

After being seeded into newly regenerated tissue, MSCs can be directed to differentiate into osteoblasts which finally initiate the process of mineralization. MSCs can indirectly improve bone regeneration through the secretion of cytokines and growth factors. Two strategies are used: the MSCs are directly transplanted into the defect bone site and combined with an external scaffold; MSCs isolated from the patient and expanded ex vivo are seeded onto suitable internal 3D scaffolds which, in controlled culture conditions, proliferate and pre-differentiate [288]. The most promising is the combination of cells with scaffolds fabricated from different materials and technologies, recently summarized by Chocholata et al. [289]. Several investigations in bone tissue engineering have reported various types of MSCs combined with different scaffolds as potentially suitable for regeneration for surgical procedures in the oral and maxillofacial region [290-293]. A clinical research study reported biocomplexes fabricated from DPSCs and collagen sponges in human mandible repair with remarkable results [294].

Recently, the use of human GMSCs was considered as a strategy for accidental or trauma surgery treatment, especially for cranial bones. Three-dimensional-engineered scaffolds complexed with GMSCs could provide a new therapeutic approach to improving bone tissue regeneration [295]. 
Common bone defects in the maxilla and mandible after tooth loss include atrophy of hard and soft alveolar tissue, which result in reduced horizontal and vertical dimensions [296]. In some cases, bone regeneration is required in the atrophic mandible and for maxillary sinus augmentation and dorsal augmentation in rhinoplasty [282]. The atrophic mandible, characterized by a vertical height of less than $20 \mathrm{~mm}$, presents hypovascularity that can determine tooth loss and alveolar processes. The atrophic resorption patterns create important anatomical changes with the risk of soft tissue breakdown and dehiscence as secondary effect of deficiency in blood supply in that area because of the lack of muscle attachments. In Gjerde et al. [297], regeneration of severe mandibular ridge resorption was performed using bone-marrow-derived MSCs, which is a less invasive approach than classical bone grafting. Aspirated from the posterior iliac crest, the bone marrow cells and the plastic adherent cells were expanded in culture medium with human platelet lysate. Afterwards, the cells were inserted into the defect together with biphasic calcium phosphate granules. A significant new regenerated bone formation was induced with a volume appropriate for dental implant installation [297]. Di Stefano et al. [298] tested the effectiveness of enzymatically deantigenated equine bone block as a scaffold during horizontal augmentation of the lower jaw for guided bone regeneration. In addition, they reported the augmentation of a partially edentulous atrophic mandible using an equine-derived block with an expanded polytetrafluoroethylene membrane. The new regenerated bone allowed for a definitive prosthesis [298].

\subsubsection{Cartilage Regeneration}

The temporomandibular joint (TMJ) is affected by many diseases and defects that can compromise the cartilaginous layer of the condyle. Cartilage is an avascular tissue that has a limited capacity to heal and repair because of limited supplies of nutrients and does not have the availability of blood-borne or perivascular progenitor cells. Many surgical procedures are available for TMJ disorders, but all are aggressive and dangerous for the patient. From simple arthrocentesis to joint replacement, they cannot produce integral regeneration [299].

A recent research objective is the insertion a cell source to manufacture neocartilage after displacement of the dysfunctional disc. Biocompatible scaffolds seeded with cells and biological modulators can be useful in such a process. Thus, the regeneration process of the TMJ is based on several main factors, such as scaffold design and material, stem cells, bioactive agents, biochemical compatibility between the scaffold and the surrounding environment, and the ability of the host to accept the scaffold and facilitate tissue formation [300]. Both natural and synthetic polymers were used for the regeneration of soft cartilage tissue. Collagen, gelatin, hyaluronic acid, fibrin, silk, agarose, polylactic acid, or poly vinyl alcohol are only some of the materials that can be used in cartilage tissue engineering, as reviewed by Jazayeri et al. [300]. Extracting SCs from the synovial capsule surrounding the joint holds has been proven to be a promising choice for generating neocartilage. Recently, Shetty et al. concluded that human DPSCs in porous chitosan scaffolds are useful for regenerating chondrogenic cells [301].

\subsection{Tooth Regeneration}

Nowadays, the regeneration of the entire tooth and its replacement represent the final objective of tooth tissue engineering (Figure 5). Even if dental tissues have no capacity for self-regeneration, the teeth are an important source of SCs, offering possible regeneration based on a patient's own SCs. This technique could be used to create replacements for dental implants and eliminate the risk of rejection, as the new tooth would not be a foreign tissue [302].

Tooth regeneration research using adult SCs has been considered. Autologous DPSCs or postnatal tooth germ cells have limited window of availability, so they can only provide a casual source for whole-tooth regeneration.

The classical tissue recombination has been improved by using collagen drops on the organic culture or by seeding the re-aggregated germ cells on biodegradable polymers. The experiments on animals 
have shown that tooth-like organs, with dentin and enamel, can be developed by ectopic subcutaneous grafting these cell aggregates under the renal capsule or into the anterior eye chamber [303].

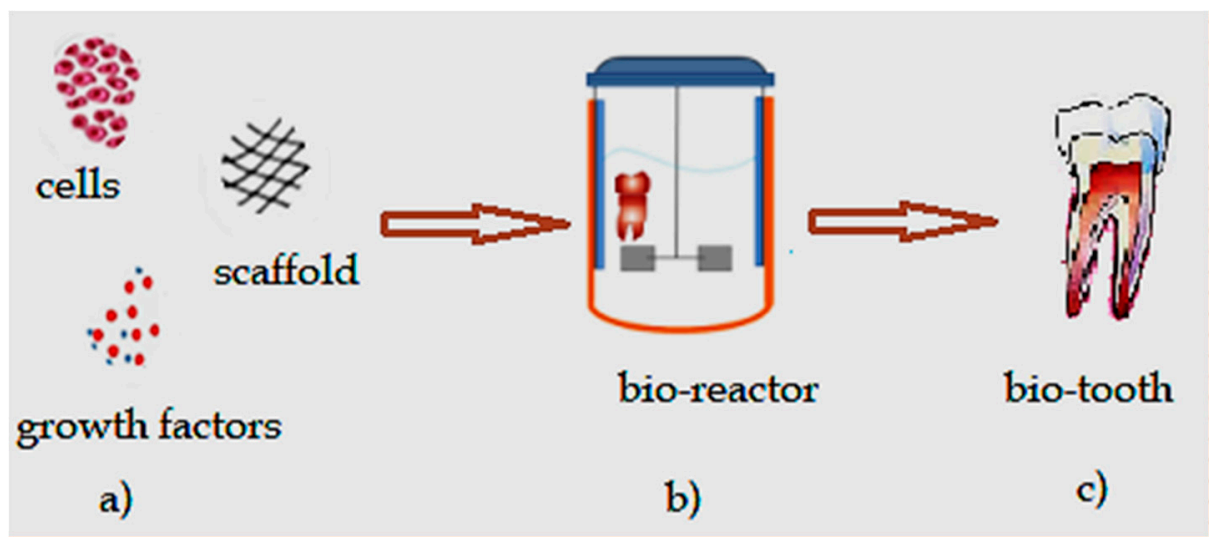

Figure 5. Bio-engineered tooth: (a) selection of dental cells sources and scaffolds, with addition of growth factors, (b) bio-reactor for in vitro development of bio-engineered tooth bud, (c) bio-tooth.

After implantation into the animal's jaw, a whole tooth could be generated. Ikeda et al. [304] reported successful tooth replacement in an adult mouse, representing an important first step for the transplantation of the bioengineered tooth germ into the alveolar bone to replace a lost tooth. Teeth represent a particular goal for regenerative medicine; they are difficult to recreate due to their complicated structure and numerous functions such as in articulation, mastication, and facial aesthetics. Thus, even if incontestable advancement can be achieved, tooth regeneration based on SCs still has uncertain applicability. Several research studies have reported similar tooth tissues regenerated using different cell types on biodegradable scaffolds, such as silk protein, chitosan [305].

SCs collected from postnatal tooth buds of animals, self-replicated and differentiated in vitro, have been seeded onto a biodegradable scaffold. Their in vivo maturation was achieved by transplanting the seeded scaffolds either into the renal capsule or the omentum, followed by their reimplantation into an extracted tooth place or the jaw [31]. However, by using non-human cells, the chance of immune rejection exists [306].

Ono et al. performed the autologous transplantation of a bioengineered tooth germ in a postnatal canine model and reported functional tooth restoration. The results of the study represented a relevant advancement in whole-organ replacement therapy as well as a practical model for future attempts [307]. Nevertheless, entire-tooth engineering or regeneration is still complicated, and the literature on the subject highlights several problems, such as how to program the stem and progenitor cells to develop into tooth-specific cell types [308,309].

Based on the proven successful applications of SCs in dental tissue regeneration, researchers realize whole-tooth regeneration could be achieved by applying one of two hybrid strategies. The first involves biological PDL and the tooth crown, obtained using stem cells, combined with a metallic or ceramic implant [310]; the second involves a biologically regenerated tooth root combined with a prosthetic crown [311].

\section{Concluding Remarks and Future Perspectives}

In recent decades, major progress has been achieved in regenerative medicine and especially in tissue engineering, which has been used in many clinical applications, but only the first steps toward these goals have been completed [312]. Tissue engineering based on stem or progenitor cells is a promising approach for restoring the integrity of dental and maxillofacial tissues. Research and clinical applications of dental SCs have proven their utility and advantages, such as the capacity for self-regeneration and multidirectional differentiation, easy accessibility, and, importantly, low autologous transplant rejection. However, for real and stable tissue regeneration in dentistry, 
many other theoretical and technological approaches must be applied in the future for the induction and genetic modification of orofacial SCs. Regeneration of the entire tooth is a major objective for replacing classical dental implants and overcoming their disadvantages. Such an approach would allow the reconstruction or regeneration of teeth in the near future, significantly increasing the quality of dental health.

Future studies are still necessary to identify suitable SCs for performing the physiological role of native tissue, growth factors able to support both cellular differentiation and replication, and to determine the role of microvascularization in tissue regeneration.

Author Contributions: Conceptualization, L.-C.R. and A.M.; software, D.C. and M.B.; validation, L.C.A. and L.-C.R.; data curation, A.M.; writing-original draft preparation, A.M., D.C., M.B., L.-C.R. and L.C.A.; writing-review and editing, L.C.A.; supervision, L.-C.R., L.C.A., E.A.B. and M.L.; funding acquisition, A.M. All authors have read and agreed to the published version of the manuscript.

Funding: This research received no external funding.

Conflicts of Interest: The authors declare no conflict of interest.

\section{Abbreviations}

\begin{tabular}{|c|c|}
\hline ECM & Extracellular matrix \\
\hline SCs & Stem cells \\
\hline ESCs & Embryonic stem cells \\
\hline ASCs & Adult stem cells \\
\hline iPSCs & Induced pluripotent stem cells \\
\hline MSCs & Mesenchymal stem cells \\
\hline DPSCs & Dental pulp stem cells \\
\hline PDLSCs & Periodontal ligament stem cells \\
\hline PDL & Periodontal ligament \\
\hline SCAPs & Stem cells from apical papilla \\
\hline DFCs & Dental follicle stem cells \\
\hline TGPCs & Tooth germ progenitor cells \\
\hline SHEDs & Stem cells of human exfoliated deciduous teeth \\
\hline ABMSCs & Alveolar bone-derived mesenchymal stem cells \\
\hline SGDSCs & Salivary gland-derived stem cells \\
\hline OMSCs & Oral mucosa-derived mesenchymal stem cells \\
\hline OESCs & Oral epithelial stem cells \\
\hline GMSCs & Gingiva-derived mesenchymal stem cells \\
\hline PSCs & Periosteum-derived stem cells \\
\hline PLA & Poly(lactic acid) \\
\hline PGA & Poly(glycolic acid) \\
\hline PLGA & Poly(lactic-co-glycolic acid) \\
\hline PCL & Poly(caprolactone) \\
\hline HA & Hydroxyapatite \\
\hline PVDF-TrFE & Poly(vinylidene fluoride-trifluoroethylene) \\
\hline nBGC & Nanobioactive glass ceramic \\
\hline RET & Regenerative endodontic therapy \\
\hline MTA & Mineral trioxide aggregate \\
\hline AAE & American Association of Endodontists' \\
\hline EDTA & Ethylenediaminetetraacetic acid \\
\hline $\mathrm{CHX}$ & Chlorhexidine \\
\hline TAP & Triple antibiotic paste \\
\hline PRP & Platelet-rich plasma \\
\hline PRF & Platelet-rich fibrin \\
\hline $\mathrm{BC}$ & Blood clot \\
\hline GTR & Guided tissue regeneration \\
\hline TMJ & Temporomandibular joint \\
\hline
\end{tabular}




\section{References}

1. Tatullo, M.; Marrelli, M.; Paduano, F. The regenerative medicine in oral and maxillofacial surgery: The most important innovations in the clinical application of mesenchymal stem cells. Int. J. Med. Sci. 2015, 12, 72-77. [CrossRef] [PubMed]

2. Rai, R. Tissue engineering: Step ahead in maxillofacial reconstruction. J. Int. Oral Health 2015, 9, $138-142$.

3. Borrelli, M.R.; Hu, M.S.; Longaker, M.T.; Lorenz, H.P. Tissue engineering and regenerative medicine in craniofacial reconstruction and facial aesthetics. J. Craniofac. Surg. 2020, 31, 15-27. [CrossRef] [PubMed]

4. Upadhyay, R.K. Role of Biological Scaffolds, Hydro Gels and Stem Cells in Tissue Regeneration Therapy. Adv. Tissue Eng. Regen. Med. Open Access 2017, 2, 121-135. [CrossRef]

5. Zhang, K.; Wang, S.; Zhou, C.; Cheng, L.; Gao, X.; Xie, X.; Sun, J.; Wang, H.; Weir, M.D.; Reynolds, M.A.; et al. Advanced smart biomaterials and constructs for hard tissue engineering and regeneration. Bone Res. 2018, 6, 31. [CrossRef]

6. Guan, X.; Avci-Adali, M.; Alarcin, E.; Cheng, H.; Kashaf, S.S.; Li, Y.; Chawla, A.; Jang, H.L.; Khademhosseini, A. Development of hydrogels for regenerative engineering. Biotechnol. J. 2017, 12, 1600394. [CrossRef]

7. Gao, Z.H.; Hu, L.; Liu, G.L.; Wei, F.L.; Liu, Y.; Liu, Z.H.; Fan, Z.P.; Zhang, C.M.; Wang, J.S.; Wang, S.L. Bio-Root and Implant-Based Restoration as a Tooth Replacement Alternative. J. Dent. Res. 2016, 95, $642-649$. [CrossRef]

8. Har, A.; Park, J.C. Dental Stem Cells and Their Applications. Chin. J. Dent. Res. 2015, 18, 207-212. [CrossRef]

9. Ledesma-Martínez, E.; Mendoza-Núñez, V.M.; Santiago-Osorio, E. Mesenchymal Stem Cells Derived from Dental Pulp: A Review. Stem Cells Int. 2016, 1-12. [CrossRef]

10. Drela, K.; Stanaszek, L.; Nowakowski, A.; Kuczynska, Z.; Lukomska, B. Experimental strategies of mesenchymal stem cell propagation: Adverse events and potential risk of functional changes. Stem Cells Int. 2019, 2019, 7012692. [CrossRef]

11. Zhou, T.; Pan, J.; Wu, P.; Huang, R.; Du, W.; Zhou, Y.; Wan, M.; Fan, Y.; Xu, X.; Zhou, X.; et al. Dental Follicle Cells: Roles in Development and Beyond. Stem Cells Int. 2019, 2019, 9159605. [CrossRef] [PubMed]

12. The Nobel Prize in Physiology or Medicine-2012 Press Release. Available online: www.nobelprize.org/ prizes/medicine/2012/press-release/ (accessed on 12 November 2020).

13. Gurdon, J.B. The Developmental Capacity of Nuclei Taken from Intestinal Epithelium Cells of Feeding Tadpoles. J. Embryol. Exp. Morphol. 1962, 10, 622-640. [PubMed]

14. Yamanaka, S. Patient-specific pluripotent stem cells become even more accessible. Cell Stem Cell 2010, 7, 1-2. [CrossRef] [PubMed]

15. Takahashi, K.; Tanabe, K.; Ohnuki, M.; Narita, M.; Ichisaka, T.; Tomoda, K.; Yamanaka, S. Induction of pluripotent stem cells from adult human fibroblasts by defined factors. Cell 2007, 131, 861-872. [CrossRef]

16. Takahashi, K.; Yamanaka, S. Induction of pluripotent stem cells from mouse embryonic and adult fibroblast cultures by defined factors. Cell 2006, 126, 663-676. [CrossRef]

17. Zakrzewski, W.; Dobrzyński, M.; Szymonowicz, M.; Rybak, Z. Stem cells: Past, present, and future. Stem Cell Res. Ther. 2019, 10, 1-22. [CrossRef]

18. Berebichez-Fridman, R.; Pablo, R.; Montero-Olvera, P.R. Sources and Clinical Applications of Mesenchymal Stem Cells. Sultan Qaboos Univ. Med. J. 2018, 18, e264. [CrossRef]

19. Cao, C.; Tarlé, S.; Kaigler, D. Characterization of the immunomodulatory properties of alveolar bone-derived mesenchymal stem cells. Stem Cell Res. 2020, 11, 102. [CrossRef]

20. Liu, J.; Yu, F.; Sun, Y.; Jiang, B.; Zhang, W.; Yang, J.; Xu, G.T.; Liang, A.; Liu, S. Concise reviews: Characteristics and potential applications of human dental tissue-derived mesenchymal stem cells. Stem Cells 2015, 33, 627-638. [CrossRef]

21. Pisciotta, A.; Carnevale, G.; Meloni, S.; Riccio, M.; De Biasi, S.; Gibellini, L. Human dental pulp stem cells (hDPSCs): Isolation, enrichment, and comparative differentiation of two sub-populations. BMC Dev. Biol. 2015, 15, 14. [CrossRef]

22. Hollands, P.; Aboyeji, D.; Orcharton, M. Dental pulp stem cells in regenerative medicine. Br. Dent. J. 2018, 224, 747. [CrossRef]

23. Tsutsui, T.W. Dental Pulp Stem Cells: Advances to Applications. Stem Cells Cloning Adv. Appl. 2020, 13, 33-42. [CrossRef]

24. Sharpe, P.T. Dental mesenchymal stem cells. Development 2016, 143, 2273-2280. [CrossRef] [PubMed] 
25. Kang, J.; Fan, W.; Deng, Q.; He, H.; Huang, F. Stem Cells from the Apical Papilla: A Promising Source for Stem Cell-Based Therapy. BioMed Res. Int. 2019, 2019, 6104738. [CrossRef]

26. Tian, Y.; Bai, D.; Guo, W.; Li, J.; Zeng, J.; Yang, L.; Jiang, Z.; Feng, L.; Yu, M.; Tian, W. Comparison of human dental follicle cells and human periodontal ligament cells for dentin tissue regeneration. Regen. Med. 2015, 10, 461-479. [CrossRef]

27. Dave, J.R.; Tomar, G.B. Dental Tissue-Derived Mesenchymal Stem Cells: Applications in Tissue Engineering. Crit. Rev. Biomed. Eng. 2018, 46, 429-468. [CrossRef]

28. Paz, A.G.; Maghaireh, H.; Mangano, F.G. Stem Cells in dentistry: Types of intra- and extraoral tissue-derived stem cells and clinical applications. Stem Cells Int. 2018, 2018, 4313610. [CrossRef]

29. Motwani, B.K.; Singh, M.; Kaur, G.; Singh, S.; Gangde, P.O. Stem cells: A new paradigm in dentistry. Stem Cells 2016, 2, 140. [CrossRef]

30. Chalisserry, E.P.; Nam, S.Y.; Park, S.H.; Anil, S. Therapeutic potential of dental stem cells. J. Tissue Eng. 2017, 8, 1-17. [CrossRef]

31. Somani, R.; Jaidka, S.; Bajaj, N.; Arora, S. Miracle cells for natural dentistry-A review. J. Oral Biol. Craniofac. Res. 2017, 7, 49-53. [CrossRef]

32. Taguchi, T.; Yanagi, Y.; Yoshimaru, K.; Zhang, X.Y.; Matsuura, T.; Nakayama, K.; Kobayashi, E.; Yamaza, H.; Nonaka, K.; Ohga, S.; et al. Regenerative medicine using stem cells from human exfoliated deciduous teeth (SHED): A promising new treatment in pediatric surgery. Surg. Today 2019, 49, 316-322. [CrossRef] [PubMed]

33. Grawish, M.E. Gingival-derived mesenchymal stem cells: An endless resource for regenerative dentistry. World J. Stem Cells 2018, 10, 116-118. [CrossRef] [PubMed]

34. Tonk, C.; Witzler, M.; Schulze, M.; Tobiasch, E. Mesenchymal Stem Cells. In Essential Current Concepts in Stem Cell Biology; Brand-Saberi, B., Ed.; Springer: Berlin, Germany, 2020; pp. 21-39.

35. Baranova, J.; Büchner, D.; Götz, W.; Schulze, M.; Tobiasch, E. Tooth Formation: Are the Hardest Tissues of Human Body Hard to Regenerate? Int. J. Mol. Sci. 2020, 21, 4031. [CrossRef]

36. Marin, E.; Boschetto, F.; Pezzotti, G. Biomaterials and biocompatibility: An historical overview. J. Biomed. Mater. Res. 2020, 108, 1617-1633. [CrossRef]

37. Tian, H.; Tang, Z.; Zhuang, X.; Chen, X.; Jing, X. Biodegradable synthetic polymers: Preparation, functionalization and biomedical application. Prog. Polym. Sci. 2012, 37, 237-280. [CrossRef]

38. Xie, Y.; Chen, Y.; Sun, M.; Ping, Q. A mini review of biodegradable calcium phosphate nanoparticles for gene delivery. Curr. Pharm. Biotechnol. 2013, 14, 918-925. [CrossRef]

39. Bergmann, C.P.; Stumpf, A. Biomaterials. In Dental Ceramics: Microstructure, Properties and Degradation; Bergmann, C., Stumpf, A., Eds.; Springer: Berlin/Heidelberg, Germany, 2013; pp. 9-13. [CrossRef]

40. Ferrage, L.; Bertrand, G.; Lenormand, P.; Grossin, D.; Ben-Nissan, B. A review of the additive manufacturing (3DP) of bioceramics: Alumina, zirconia (PSZ) and hydroxyapatite. J. Aust. Ceram. Soc. 2017, 53, 11-20. [CrossRef]

41. Liu, X.; Ma, P.X. Polymeric Scaffolds for Bone Tissue Engineering. Ann. Biomed. Eng. 2004, 32, 477-486. [CrossRef]

42. Nair, L.S.; Laurencin, C.T. Biodegradable polymers as biomaterials. Prog. Polym. Sci. 2007, 32, $762-798$. [CrossRef]

43. Banerjee, A.; Chatterjee, K.; Madras, G. Enzymatic degradation of polymers: A brief review. Mater. Sci. Technol. 2014, 30, 567-573. [CrossRef]

44. Rey-Vinolas, S.; Engel, E.; Mateos-Timoneda, M. Polymers for bone repair. In Bone Repair Biomaterials, 2nd ed.; Pawelec, K.M., Planell, J.A., Eds.; Woodhead Publishing: Cambridge, UK, 2019; pp. 179-197. [CrossRef]

45. Rezwan, K.; Chen, Q.Z.; Blaker, J.J.; Boccaccini, A.R. Biodegradable and bioactive porous polymer/inorganic composite scaffolds for bone tissue engineering. Biomaterials 2006, 27, 3413-3431. [CrossRef] [PubMed]

46. Ulery, B.D.; Nair, L.S.; Laurencin, C.T. Biomedical Applications of Biodegradable Polymers. J. Polym. Sci. 2011, 49, 832-864. [CrossRef]

47. Maurus, P.B.; Kaeding, C.C. Bioabsorbable implant material review. Oper. Tech. Sports Med. 2004, 12, 158-160. [CrossRef]

48. Gentile, P.; Chiono, V.; Carmagnola, I.; Hatton, P.V. An Overview of Poly(lactic-co-glycolic)Acid (PLGA)-Based Biomaterials for Bone Tissue Engineering. Int. J. Mol. Sci. 2014, 15, 3640-3659. [CrossRef] 
49. Elmowafy, E.M.; Tiboni, M.; Soliman, M.E. Biocompatibility, biodegradation and biomedical applications of poly(lactic acid)/poly(lactic-co-glycolic acid)micro and nanoparticles. J. Pharm. Investig. 2019, 49, 347-380. [CrossRef]

50. Derby, B. Printing and prototyping of tissues and scaffolds. Science 2012, 338, 921-926. [CrossRef]

51. Matsiko, A.; Gleeson, J.P.; O’Brien, F.J. Scaffold mean pore size influences mesenchymal stem cell chondrogenic differentiation and matrix deposition. Tissue Eng. Part A 2015, 21, 486-497. [CrossRef]

52. Domingos, M.; Intranuovo, F.; Russo, T.; De Santis, R.; Gloria, A.; Ambrosio, L.; Ciurana, J.; Bartolo, P. The first systematic analysis of 3D rapid prototyped poly(epsilon-caprolactone) scaffolds manufactured through BioCell printing: The effect of pore size and geometry on compressive mechanical behaviour and in vitro hMSC viability. Biofabrication 2013, 5, 045004. [CrossRef]

53. Motamedian, S.R.; Hosseinpour, S.; Ahsaie, M.G.; Khojasteh, A. Smart scaffolds in bone tissue engineering: A systematic review of literature. World J. Stem Cells 2015, 7, 657-668. [CrossRef]

54. Kaigler, D.; Wang, Z.; Horger, K.; Mooney, D.J.; Krebsbach, P.H. VEGF scaffolds enhance angiogenesis and bone regeneration in irradiated osseous defects. J. Bone Min. Res. 2006, 21, 735-744. [CrossRef]

55. Khan, F.; Tanaka, M. Designing smart biomaterials for tissue engineering. Int. J. Mol. Sci. 2018, $19,17$. [CrossRef]

56. Mittal, A.; Negi, P.; Garkhal, K.; Verma, S.; Kumar, N. Integration of porosity and bio-functionalization to form a 3D scaffold: Cell culture studies and in vitro degradation. Biomed. Mater. 2010, 5, 045001. [CrossRef] [PubMed]

57. Zeng, D.; Zhang, X.; Wang, X.; Huang, Q.; Wen, J.; Miao, X.; Peng, L.; Li, Y.; Jiang, X. The osteoimmunomodulatory properties of MBG scaffold coated with amino functional groups. Artif. Cells Nanomed. Biotechnol. 2018, 46, 1425-1435. [CrossRef] [PubMed]

58. Chen, Z.; Mao, X.; Tan, L.; Friis, T.; Wu, C.; Crawford, R.; Xiao, Y. Osteoimmunomodulatory properties of magnesium scaffolds coated with $\beta$-tricalcium phosphate. Biomaterials 2014, 35, 8553-8565. [CrossRef] [PubMed]

59. Liu, X.; Zhao, K.; Gong, T.; Song, J.; Bao, C.; Luo, E.; Weng, J.; Zhou, S. Delivery of growth factors using a smart porous nanocomposite scaffold to repair a mandibular bone defect. Biomacromolecules 2014, 15, 1019-1030. [CrossRef] [PubMed]

60. Damaraju, S.M.; Shen, Y.; Elele, E.; Khusid, B.; Eshghinejad, A.; Li, J.; Jaffe, M.; Arinzeh, T.L. Three-dimensional piezoelectric fibrous scaffolds selectively promote mesenchymal stem cell differentiation. Biomaterials 2017, 149, 51-62. [CrossRef] [PubMed]

61. Augustine, R.; Dan, P.; Sosnik, A.; Kalarikkal, N.; Tran, N.; Vincent, B.; Thomas, S.; Menu, P.; Rouxel, D. Electrospun poly(vinylidene fluoride-trifluoroethylene)/zinc oxide nanocomposite tissue engineering scaffolds with enhanced cell adhesion and blood vessel formation. Nano Res. 2017, 10, 3358-3376. [CrossRef]

62. Liu, D.; Yang, F.; Xiong, F.; Gu, N. The Smart Drug Delivery System and Its Clinical Potential. Theranostics 2016, 6, 1306-1323. [CrossRef]

63. Kondiah, P.J.; Choonara, Y.E.; Kondiah, P.P.D.; Marimuthu, T.; Kumar, P.; Du Toit, L.C.; Pillay, V. A Review of Injectable Polymeric Hydrogel Systems for Application in Bone Tissue Engineering. Molecules 2016, 21, 1580. [CrossRef]

64. Mohd Amin, M.C.; Ahmad, N.; Pandey, M.; Jue Xin, C. Stimuli-responsive bacterial cellulose-g-poly(acrylic acid-co-acrylamide) hydrogels for oral controlled release drug delivery. Drug Dev. Ind. Pharm. 2014, 40, 1340-1349. [CrossRef]

65. Ashley, G.W.; Henise, J.; Reid, R.; Santi, D.V. Hydrogel drug delivery system with predictable and tunable drug release and degradation rates. Proc. Natl. Acad. Sci. USA 2013, 110, 2318-2323. [CrossRef] [PubMed]

66. Horev, B.; Klein, M.I.; Hwang, G.; Li, Y.; Kim, D.; Koo, H.; Benoit, D.S. pH-activated nanoparticles for controlled topical delivery of farnesol to disrupt oral biofilm virulence. ACS Nano 2015, 9, 2390-2404. [CrossRef] [PubMed]

67. Luo, Z.; Zhang, S.; Pan, J.; Shi, R.; Liu, H.; Lyu, Y.; Han, X.; Li, Y.; Yang, Y.; Xu, Z.; et al. Time-responsive osteogenic niche of stem cells: A sequentially triggered, dual-peptide loaded, alginate hybrid system for promoting cell activity and osteo-differentiation. Biomaterials 2018, 163, 25-42. [CrossRef] [PubMed]

68. Sant, S.; Hancock, M.J.; Donnelly, J.P.; Iyer, D.; Khademhosseini, A. Biomimetic gradient hydrogels for tissue engineering. Can. J. Chem. Eng. 2010, 88, 899-911. [CrossRef] [PubMed] 
69. Sheikhpour, M.; Barani, L.; Kasaeian, A. Biomimetics in drug delivery systems: A critical review. J. Control Release 2017, 253, 97-109. [CrossRef]

70. Carlo Reis, E.C.; Borges, A.P.; Araújo, M.V.; Mendes, V.C.; Guan, L.; Davies, J.E. Periodontal regeneration using a bilayered PLGA/calcium phosphate construct. Biomaterials 2011, 32, 9244-9253. [CrossRef]

71. Sowmya, S.; Mony, U.; Jayachandran, P.; Reshma, S.; Kumar, R.A.; Arzate, H.; Nair, S.V.; Jayakumar, R. Tri-layered nanocomposite hydrogel scaffold for the concurrent regeneration of cementum, periodontal ligament, and alveolar bone. Adv. Healthc. Mater. 2017, 6, 1601251. [CrossRef]

72. Weir, M.D.; Ruan, J.; Zhang, N.; Chow, L.C.; Zhang, K.; Chang, X.; Bai, Y.; Xu, H.H.K. Effect of calcium phosphate nanocomposite on in vitro remineralization of human dentin lesions. Dent. Mater. 2017, 33, 1033-1044. [CrossRef]

73. Li, L.; He, J.; Eckert, R.; Yarbrough, D.; Lux, R.; Anderson, M.; Shi, W. Design and characterization of an acid-activated antimicrobial peptide. Chem. Biol. Drug Des. 2010, 75, 127-132. [CrossRef]

74. Yang, Y.; Reipa, V.; Liu, G.; Meng, Y.; Wang, X.; Mineart, K.P.; Prabhu, V.M.; Shi, W.; Lin, N.J.; He, X.; et al. $\mathrm{pH}$-sensitive compounds for selective inhibition of acid-producing bacteria. ACS Appl. Mater. Interfaces 2018, 10, 8566-8573. [CrossRef]

75. Cheng, L.; Weir, M.D.; Zhang, K.; Wu, E.J.; Xu, S.M.; Zhou, X.; Xu, H.H. Dental plaque microcosm biofilm behavior on calcium phosphate nanocomposite with quaternary ammonium. Dent. Mater. 2012, 28, 853-862. [CrossRef] [PubMed]

76. Wang, S.; Wang, H.; Ren, B.; Li, X.; Wang, L.; Zhou, H.; Weir, M.D.; Zhou, X.; Masri, R.M.; Oates, T.W.; et al. Drug resistance of oral bacteria to new antibacterial dental monomer dimethylaminohexadecyl methacrylate. Sci. Rep. 2018, 8, 5509. [CrossRef] [PubMed]

77. Li, F.; Weir, M.D.; Xu, H.H. Effects of quaternary ammonium chain length on antibacterial bonding agents. J. Dent. Res. 2013, 92, 932-938. [CrossRef] [PubMed]

78. Li, L.; Zhu, Y.Q.; Jiang, L.; Peng, W.; Ritchie, H.H. Hypoxia Promotes Mineralization of Human Dental Pulp Cells. J. Endod. 2011, 37, 799-802. [CrossRef] [PubMed]

79. Huang, G.T.J.; Shagramanova, K.; Chan, S.W. Formation of Odontoblast-Like Cells from Cultured Human Dental Pulp Cells on Dentin In Vitro. J. Endod. 2006, 32, 1066-1073. [CrossRef]

80. Del Angel-Mosqueda, C.; Gutiérrez-Puente, Y.; López-Lozano, A.P.; Romero-Zavaleta, R.E.; Mendiola-Jiménez, A.; Medina-De la Garza, C.E.; Márquez, M.M.; De la Garza-Ramos, M.A. Epidermal growth factor enhances osteogenic differentiation of dental pulp stem cells in vitro. Head Face Med. 2015, 11, 29. [CrossRef]

81. Rusu, L.C.; Nedelcu, I.V.; Albu, M.G.; Sonmez, M.; Voicu, G.; Radulescu, M.; Ficai, D.; Ficai, A.; Negrutiu, M.L.; Sinescu, C. Tetracycline Loaded Collagen/Hydroxyapatite Composite Materials for Biomedical Applications. J. Nanomater. 2015, 2015, 361969. [CrossRef]

82. Patrascu, J.M.; Nedelcu, I.A.; Sonmez, M.; Ficai, D.; Ficai, A.; Vasile, B.S.; Ungureanu, C.; Albu, M.G.; Andor, B.; Andronescu, E.; et al. Composite Scaffolds Based on Silver Nanoparticles for Biomedical Applications. J. Nanomater. 2015, 2015, 587989. [CrossRef]

83. Rusu, L.C.; Sinescu, C.; Negrutiu, M.L.; Ardelean, L.; Ogodescu, A.; Fabricky, M.; Petrescu, E.; Rominu, R.; Topala, F.; Rominu, M.; et al. Application for regenerative dentistry: The collagen matrices with lidocaine. Computational Engineering in System Applications. In Proceedings of the International Conference on Energy, Environment, Economics, Devices, Systems, Communications, Computers, Iasi, Romania, 1-3 July 2011; pp. 60-64.

84. Rusu, L.C.; Manescu, A.; Negrutiu, M.L.; Sinescu, C.; Ardelean, S.; Hoinoiu, B.; Rominu, M. The Micro CT Evaluation of Different Types of Matrices in Rats Bone Augumentation. Key Eng. Mater. 2013, 587, 338-342. [CrossRef]

85. Rusu, L.C.; Negrutiu, M.L.; Sinescu, C.; Hoinoiu, B.; Topala, F.I.; Duma, V.F.; Rominu, M.; Podoleanu, A.G. Time domain optical coherence tomography investigation of bone matrix interface in rat femurs. In Proceedings of the ISPDI 2013-Fifth International Symposium on Photoelectronic Detection and Imaging (SPIE 8914), Beijing, China, 25-27 June 2013; p. 89141H. [CrossRef]

86. Rusu, L.C.; Negrutiu, M.L.; Sinescu, C.; Hoinoiu, B.; Zaharia, C.; Ardelean, L.; Duma, V.F.; Podoleanu, A.G. Different matrix evaluation for the bone regeneration of rats' femours using time domain optical coherence tomography. In Proceedings of the Fifth International Conference on Lasers in Medicine: Biotechnologies Integrated in Daily Medicine (SPIE 8925), Timisoara, Romania, 19-21 September 2013; p. 89250V. [CrossRef] 
87. Manescu, A.; Oancea, R.; Todea, C.; Rusu, L.C.; Mazzoni, S.; Negrutiu, M.L.; Sinescu, C.; Giuliani, A. On Long Term Effects of Low Power Laser Therapy on Bone Repair: A Demonstrative Study by Synchrotron Radiation-based Phase-Contrast Microtomography. Int. J. Radiol. Imaging Technol. 2016, 2, 010. [CrossRef]

88. Baumgartner, S.; Gmeiner, R.; Schönherr, J.A.; Stampfl, J. Stereolithography-based additive manufacturing of lithium disilicate glass ceramic for dental applications. Mater. Sci. Eng. C 2020, 116, 111180. [CrossRef]

89. Jasiuk, I.; Abueidda, D.W.; Kozuch, C.; Pang, S.; Su, F.Y.; McKittrick, J. An Overview on Additive Manufacturing of Polymers. JOM 2018, 70, 275-283. [CrossRef]

90. Mederle, N.; Marin, S.; Marin, M.M.; Danila, E.; Mederle, O.; Kaya, M.G.A.; Ghica, M.V. Innovative biomaterials based on collagen-hydroxyapatite and doxycycline for bone regeneration. Adv. Mater. Sci. Eng. 2016, 2016, 3452171. [CrossRef]

91. Papaioannou, T.G.; Manolesou, D.; Dimakakos, E.; Tsoucalas, G.; Vavuranakis, M.; Tousoulis, D. 3D Bioprinting Methods and Techniques: Applications on Artificial Blood Vessel Fabrication. Acta Cardiol. Sin. 2019, 35, 284-289. [CrossRef] [PubMed]

92. Zadpoor, A.A.; Malda, J. Additive manufacturing of biomaterials, tissues, and organs. Ann. Biomed. Eng. 2017, 45, 1-11. [CrossRef]

93. Ngo, T.D.; Kashani, A.; Imbalzano, G.; Nguyen, K.T.Q.; Hui, D. Additive manufacturing (3D printing): A review of materials, methods, applications and challenges. Compos. B Eng. 2018, 143, 172-196. [CrossRef]

94. Murphy, S.V.; Atala, A. 3D bioprinting of tissues and organs. Nat. Biotechnol. 2014, 32, 773-785. [CrossRef]

95. Wang, X.; Ao, Q.; Tian, X.; Fan, J.; Wei, Y.; Hou, W.; Tong, H.; Bai, S. 3D bioprinting technologies for hard tissue and organ engineering. Materials 2016, 9, 802. [CrossRef]

96. Ji, X.; Zhu, H.; Zhao, L.; Xiao, J. Recent advances in 3D bioprinting for the regeneration of functional cartilage. Regen. Med. 2018, 13, 73-87. [CrossRef]

97. Nakamura, M.; Kobayashi, A.; Takagi, F.; Watanabe, A.; Hiruma, Y.; Ohuchi, K.; Iwasaki, Y.; Horie, M.; Morita, I.; Takatani, S. Biocompatible inkjet printing technique for designed seeding of individual living cells. Tissue Eng. 2005, 11, 1658-1666. [CrossRef]

98. Saunders, R.E.; Gough, J.E.; Derby, B. Delivery of human fibroblast cells by piezoelectric drop-on-demand inkjet printing. Biomaterials 2008, 29, 193-203. [CrossRef] [PubMed]

99. Catros, S.; Fricain, J.C.; Guillotin, B.; Pippenger, B.; Bareille, R.; Remy, M.; Lebraud, E.; Desbat, B.; Amedee, J.; Guillemot, F. Laser-assisted bioprinting for creating on-demand patterns of human osteoprogenitor cells and nanohydroxyapatite. Biofabrication 2011, 3, 025001. [CrossRef] [PubMed]

100. Guillemot, F.; Souquet, A.; Catros, S.; Guillotin, B. Laser-assisted cell printing: Principle, physical parameters versus cell fate and perspectives in tissue engineering. Nanomedicine 2010, 5, 507-515. [CrossRef] [PubMed]

101. Lin, H.; Zhang, D.; Alexander, P.G.; Yang, G.; Tan, J.; Cheng, A.W.; Tuan, R.S. Application of visible light-based projection stereolithography for live cell-scaffold fabrication with designed architecture. Biomaterials 2013, 34, 331-339. [CrossRef] [PubMed]

102. Li, J.; Chen, M.; Fan, X.; Zhou, H. Recent advances in bioprinting techniques: Approaches, applications and future prospects. J. Transl. Med. 2016, 14, 271. [CrossRef]

103. Theus, A.S.; Ning, L.; Hwang, B.; Gil, C.; Chen, S.; Wombwell, A.; Mehta, R.; Serpooshan, V. Bioprintability: Physiomechanical and Biological Requirements of Materials for 3D Bioprinting Processes. Polymers 2020, 12, 2262. [CrossRef]

104. Dorishetty, P.; Dutta, N.K.; Choudhury, N.R. Bioprintable tough hydrogels for tissue engineering applications. Adv. Colloid Interface Sci. 2020, 281, 102163. [CrossRef]

105. Compaan, A.M.; Christensen, K.; Huang, Y. Inkjet Bioprinting of 3D Silk Fibroin Cellular Constructs Using Sacrificial Alginate. ACS Biomater. Sci. Eng. 2017, 3, 1519-1526. [CrossRef]

106. Jose, R.R.; Rodriguez, M.J.; Dixon, T.A.; Omenetto, F.; Kaplan, D.L. Evolution of Bioinks and Additive Manufacturing Technologies for 3D Bioprinting. ACS Biomater. Sci. Eng. 2016, 2, 1662-1678. [CrossRef]

107. Nicodemus, G.D.; Bryant, S.J. Cell encapsulation in biodegradable hydrogels for tissue engineering applications. Tissue Eng. B Rev. 2008, 14, 149-165. [CrossRef]

108. Wust, S.; Godla, M.E.; Muller, R.; Hofmann, S. Tunable hydrogel composite with two-step processing in combination with innovative hardware upgrade for cell-based three-dimensional bioprinting. Acta Biomater. 2014, 10, 630-640. [CrossRef] [PubMed] 
109. Duffy, R.M.S.Y.; Feinberg, A.W. Understanding the role of ECM protein composition and geometric micropatterning for engineering human skeletal muscle. Ann. Biomed. Eng. 2016, 44, 2076-2089. [CrossRef] [PubMed]

110. Hinton, T.J.; Jallerat, Q.; Palchesko, R.N.; Park, J.H.; Grodzicki, M.S.; Shue, H.J.; Ramadan, M.H.; Hudson, A.R.; Feinberg, A.W. Three-dimensional printing of complex biological structures by freeform reversible embedding of suspended hydrogels. Sci. Adv. 2015, 1, e1500758. [CrossRef] [PubMed]

111. Levato, R.; Visser, J.; Planell, J.A.; Engel, E.; Malda, J.; Mateos-Timoneda, M.A. Biofabrication of tissue constructs by 3D bioprinting of cell-laden microcarriers. Biofabrication 2014, 6, 035020. [CrossRef] [PubMed]

112. Duarte Campos, D.F.; Blaeser, A.; Weber, M.; Jakel, J.; Neuss, S.; Jahnen-Dechent, W.; Fischer, H. Three-dimensional printing of stem cell-laden hydrogels submerged in a hydrophobic high-density fluid. Biofabrication 2013, 5, 015003. [CrossRef]

113. Gruene, M.; Deiwick, A.; Koch, L.; Schlie, S.; Unger, C.; Hofmann, N.; Bernemann, I.; Glasmacher, B.; Chichkov, B. Laser printing of stem cells for biofabrication of scaffold-free autologous grafts. Tissue Eng. C Methods 2011, 17, 79-87. [CrossRef]

114. Yan, D.; Zeng, B.; Han, Y.; Dai, H.; Liu, J.; Sun, Y.; Li, F. Preparation and laser powder bed fusion of composite microspheres consisting of poly(lactic acid) and nano-hydroxyapatite. Addit. Manuf. 2020, 34, 101305. [CrossRef]

115. Mostafaei, A.; Elliott, A.M.; Barnes, J.E.; Li, F.; Tan, W.; Cramer, C.L.; Nandwana, P.; Chmielus, M. Binder jet 3D printing-Process parameters, materials, properties, and challenges. Prog. Mater. Sci. 2020, 100707. [CrossRef]

116. Gonzalez, J.; Mireles, J.; Lin, Y.; Wicker, R. Characterization of ceramic components fabricated using binder jetting additive manufacturing technology. Ceram. Int. 2016, 42, 10559-10564. [CrossRef]

117. Pu'ad, N.M.; Haq, R.A.; Noh, H.M.; Abdullah, H.Z.; Idris, M.I.; Lee, T.C. Review on the fabrication of fused deposition modelling (FDM) composite filament for biomedical applications. Mater. Today Proc. 2020, 29, 228-232. [CrossRef]

118. Yap, Y.L.; Wang, C.; Sing, S.L.; Dikshit, V.; Yeong, W.Y.; Wei, J. Material jetting additive manufacturing: An experimental study using designed metrological benchmarks. Precis. Eng. 2017, 50, 275-285. [CrossRef]

119. Davoudinejad, A.; Diaz-Perez, L.C.; Quagliotti, D.; Pedersen, D.B.; Albajez-García, J.A.; Yagüe-Fabra, J.A.; Tosello, G. Additive manufacturing with vat polymerization method for precision polymer micro components production. Procedia CIRP 2018, 75, 98-102. [CrossRef]

120. Woesz, A.; Rumpler, M.; Stampfl, J.; Varga, F.; Fratzl-Zelman, N.; Roschger, P.; Klaushofer, K.; Fratzl, P. Towards bone replacement materials from calcium phosphates via rapid prototyping and ceramic gelcasting. Mater. Sci. Eng. C 2005, 25, 181-186. [CrossRef]

121. Lakhdar, Y.; Tuck, C.; Binner, J.; Terry, A.; Goodridge, R. Additive manufacturing of advanced ceramic materials. Prog. Mater. Sci. 2021, 116, 100736. [CrossRef]

122. Shuai, C.; Gao, C.; Nie, Y.; Hu, H.; Zhou, Y.; Peng, S. Structure and properties of nano-hydroxypatite scaffolds for bone tissue engineering with a selective laser sintering system. Nanotechnology 2011, 22, 285703. [CrossRef]

123. Miranda, P.; Pajares, A.; Saiz, E.; Tomsia, A.P.; Guiberteau, F. Fracture modes under uniaxial compression in hydroxyapatite scaffolds fabricated by robocasting. J. Biomed. Mater. Res. A 2007, 83, 646-655. [CrossRef]

124. Gao, Y.; Cao, W.L.; Wang, X.Y.; Gong, Y.D.; Tian, J.M.; Zhao, N.M.; Zhang, X.F. Characterization and osteoblast-like cell compatibility of porous scaffolds: Bovine hydroxyapatite and novel hydroxyapatite artificial bone. J. Mater. Sci. Mater. Med. 2006, 17, 815-823. [CrossRef]

125. Warnke, P.H.; Seitz, H.; Warnke, F.; Becker, S.T.; Sivananthan, S.; Sherry, E.; Liu, Q.; Wiltfang, J.; Douglas, T. Ceramic scaffolds produced by computer-assisted 3D printing and sintering: Characterization and biocompatibility investigations. J. Biomed. Mater. Res. B 2010, 93, 212-217. [CrossRef]

126. Gmeiner, R.; Deisinger, U.; Schonherr, J.; Lechner, B.; Detsch, R.; Boccaccini, A.; Stampfl, J. Additive manufacturing of bioactive glasses and silicate bioceramics. J. Ceram. Sci. Technol. 2015, 6, 75-86. [CrossRef]

127. Shuai, C.; Mao, Z.; Han, Z.; Peng, S.; Li, Z. Fabrication and characterization of calcium silicate scaffolds for tissue engineering. J. Mech. Med. Biol. 2014, 14, 1450049. [CrossRef]

128. Vorndran, E.; Klarner, M.; Klammert, U.; Grover, L.M.; Patel, S.; Barralet, J.E.; Gbureck, U. 3D Powder Printing of Beta-Tricalcium Phosphate Ceramics Using Different Strategies. Adv. Eng. Mater. 2008, 10, B67-B71. [CrossRef] 
129. Felzmann, R.; Gruber, S.; Mitteramskogler, G.; Tesavibul, P.; Boccaccini, A.R.; Liska, R.; Stampfl, J. Lithography-Based AdditiveManufacturing of Cellular Ceramic Structures. Adv. Eng. Mater. 2012, 14, 1052-1058. [CrossRef]

130. Bian, W.; Li, D.; Lian, Q.; Zhang, W.; Zhu, L.; Li, X.; Jin, Z. Design and fabrication of a novel porous implant with pre-set channels based on ceramic stereolithography for vascular implantation. Biofabrication 2011, 3, 034103. [CrossRef] [PubMed]

131. Bose, S.; Darsell, J.; Kintner, M.; Hosick, H.; Bandyopadhyay, A. Pore size and pore volume effects on alumina and TCP ceramic scaffolds. Mater. Sci. Eng. C. 2003, 23, 479-486. [CrossRef]

132. Butscher, A.; Bohner, M.; Roth, C.; Ernstberger, A.; Heuberger, R.; Doebelin, N.; von Rohr, P.R.; Müller, R. Printability of calcium phosphate powders for three-dimensional printing of tissue engineering scaffolds. Acta Biomater. 2012, 8, 373-385. [CrossRef] [PubMed]

133. Partee, B.; Hollister, S.J.; Das, S. Selective Laser Sintering Process Optimization for Layered Manufacturing of CAPAR 6501 Polycaprolactone Bone Tissue Engineering Scaffolds. J. Manuf. Sci. Eng. 2005, 128, 531-540. [CrossRef]

134. Chen, C.H.; Lee, M.Y.; Shyu, V.B.H.; Chen, Y.C.; Chen, C.T.; Chen, J.P. Surface modification of polycaprolactone scaffolds fabricated via selective laser sintering for cartilage tissue engineering. Mater. Sci. Eng. C 2014, 40, 389-397. [CrossRef]

135. Shor, L.; Güçeri, S.; Chang, R.; Gordon, J.; Kang, Q.; Hartsock, L.; An, Y.; Sun, W. Precision extruding deposition (PED) fabrication of polycaprolactone (PCL) scaffolds for bone tissue engineering. Biofabrication 2009, 1, 015003. [CrossRef]

136. Sobral, J.M.; Caridade, S.G.; Sousa, R.A.; Mano, J.F.; Reis, R.L. Three-dimensional plotted scaffolds with controlled pore size gradients: Effect of scaffold geometry on mechanical performance and cell seeding efficiency. Acta Biomater. 2011, 7, 1009-1018. [CrossRef]

137. Korpela, J.; Kokkari, A.; Korhonen, H.; Malin, M.; Närhi, T.; Seppälä, J. Biodegradable and bioactive porous scaffold structures prepared using fused deposition modeling. J. Biomed. Mater. Res. B 2013, 101, 610-619. [CrossRef]

138. Ge, Z.; Wang, L.; Heng, B.C.; Tian, X.F.; Lu, K.; Tai Weng Fan, V.; Yeo, J.F.; Cao, T.; Tan, E. Proliferation and Differentiation of Human Osteoblasts within 3D printed Poly-Lactic-co-Glycolic Acid Scaffolds. J. Biomater. Appl. 2009, 23, 533-547. [CrossRef]

139. Lee, M.; Wu, B.M.; Dunn, J.C.Y. Effect of scaffold architecture and pore size on smooth muscle cell growth. J. Biomed. Mater. Res. A 2008, 87, 1010-1016. [CrossRef] [PubMed]

140. Lee, M.; Dunn, J.C.Y.; Wu, B.M. Scaffold fabrication by indirect three-dimensional printing. Biomaterials 2005, 26, 4281-4289. [CrossRef] [PubMed]

141. Guo, T.; Holzberg, T.R.; Lim, C.G.; Gao, F.; Gargava, A.; Trachtenberg, J.E.; Mikos, A.G.; Fisher, J.P. 3D printing PLGA: A quantitative examination of the effects of polymer composition and printing parameters on print resolution. Biofabrication 2017, 9, 024101. [CrossRef]

142. Yang, B.; Qiu, Y.; Zhou, N.; Ouyang, H.; Ding, J.; Cheng, B.; Sun, J. Application of stem cells in oral disease therapy: Progresses and perspectives. Front. Physiol. 2017, 8, 197. [CrossRef]

143. Hu, M.S.; Maan, Z.N.; Wu, J.-C.; Rennert, R.C.; Hong, W.X.; Lai, T.S.; Cheung, A.T.M.; Walmsley, G.G.; Chung, M.T.; McArdle, A.; et al. Tissue Engineering and Regenerative Repair in Wound Healing. Ann. Biomed. Eng. 2014, 42, 1494-1507. [CrossRef]

144. Chatzistavrou, X.; Rao, R.R.; Caldwell, D.J.; Peterson, A.W.; McAlpin, B.; Wang, Y.Y.; Zheng, L.; Fenno, J.C.; Stegemann, J.P.; Papagerakis, P. Collagen/fibrin microbeads as a delivery system for Ag-doped bioactive glass and DPSCs for potential applications in dentistry. J. Non-Cryst. Solids 2016, 432, 143-149. [CrossRef]

145. Bakopoulou, A.; Leyhausen, G.; Volk, J.; Tsiftsoglou, A.; Garefis, P.; Koidis, P.; Geurtsen, W. Comparative analysis of in vitro osteo/odontogenic differentiation potential of human dental pulp stem cells (DPSCs) and stem cells from the apical papilla (SCAP). Archv. Oral Biol. 2011, 56, 709-721. [CrossRef]

146. Tatullo, M.; Marrelli, M.; Shakesheff, K.M.; White, L.J. Dental pulp stem cells: Function, isolation and applications in regenerative medicine. J. Tissue Eng. Regen. Med. 2015, 9, 1205-1216. [CrossRef]

147. Potdar, P.D.; Jethmalani, Y.D. Human dental pulp stem cells: Applications in future regenerative medicine. World J. Stem Cells 2015, 7, 839-851. [CrossRef]

148. Davila, J.C.; Cezar, G.G.; Thiede, M.; Strom, S.; Miki, T.; Trosko, J. Use and application of stem cells in toxicology. Toxicol. Sci. 2004, 79, 214-223. [CrossRef] [PubMed] 
149. Gronthos, S.; Mankani, M.; Brahim, J.; Robey, P.G.; Shi, S. Postnatal human dental pulp stem cells (DPSCs) in vitro and in vivo. Proc. Natl. Acad. Sci. USA 2000, 97, 13625-13630. [CrossRef] [PubMed]

150. Beltrão-Braga, P.C.; Pignatari, G.C.; Maiorka, P.C.; Oliveira, N.A.; Lizier, N.F.; Wenceslau, C.V.; Miglino, M.A.; Muotri, A.R.; Kerkis, I. Feeder-free derivation of induced pluripotent stem cells from human immature dental pulp stem cells. Cell Transplant. 2011, 20, 1707-1719. [CrossRef] [PubMed]

151. Verma, K.; Bains, R.; Bains, V.K.; Rawtiya, M.; Loomba, K.; Srivastava, S.C. Therapeutic potential of dental pulp stem cells in regenerative medicine: An overview. Dent. Res. J. 2014, 11, 302-308.

152. Almushayt, A.; Narayanan, K.; Zaki, A.E.; George, A. Dentin matrix protein 1 induces cytodifferentiation of dental pulp stem cells into odontoblasts. Gene Ther. 2006, 13, 611-620. [CrossRef]

153. Yoshida, S.; Tomokiyo, A.; Hasegawa, D.; Hamano, S.; Sugii, H.; Maeda, H. Insight into the Role of Dental Pulp Stem Cells in Regenerative Therapy. Biology 2020, 9, 160. [CrossRef]

154. Aydin, S.; Şahin, F. Stem Cells Derived from Dental Tissues. Adv. Exp. Med. Biol. 2019, 1144, $123-132$. [CrossRef]

155. Graziano, A.; d'Aquino, R.; Laino, G.; Papaccio, G. Dental pulp stem cells: A promising tool for bone regeneration. Stem Cell Rev. 2008, 4, 21-26. [CrossRef]

156. Kitagaki, J.; Miyauchi, S.; Xie, C.J.; Yamashita, M.; Yamada, S.; Kitamura, M.; Murakami, S. Effects of the proteasome inhibitor, bortezomib, on cytodifferentiation and mineralization of periodontal ligament cells. J. Periodontal Res. 2015, 50, 248-255. [CrossRef]

157. Hynes, K.; Menicanin, D.; Gronthos, S.; Bartold, P.M. Clinical utility of stem cells for periodontal regeneration. Periodontol 2000 2012, 59, 203-227. [CrossRef]

158. Han, J.; Menicanin, D.; Gronthos, S.; Bartold, P.M. Stem cells, tissue engineering and periodontal regeneration. Aust. Dent. J. 2014, 59, 117-130. [CrossRef] [PubMed]

159. Maeda, H.; Tomokiyo, A.; Fujii, S.; Wada, N.; Akamine, A. Promise of periodontal ligament stem cells in regeneration of periodontium. Stem Cell Res. 2011, 28, 33. [CrossRef]

160. Gay, I.C.; Chen, S.; MacDougall, M. Isolation and characterization of multipotent human periodontal ligament stem cells. Orthod. Craniofac. Res. 2007, 10, 149-160. [CrossRef] [PubMed]

161. Kim, S.S.; Kwon, D.W.; Im, I.; Kim, Y.D.; Hwang, D.S.; Holliday, L.S.; Donatelli, R.E.; Son, W.S.; Jun, E.S. Differentiation and characteristics of undifferentiated mesenchymal stem cells originating from adult premolar periodontal ligaments. Korean J. Orthod. 2012, 42, 307-317. [CrossRef] [PubMed]

162. Schneider, R.; Holland, G.R.; Chiego, D., Jr.; Hu, J.C.; Nör, J.E.; Botero, T.M. White mineral trioxide aggregate induces migration and proliferation of stem cells from the apical papilla. J. Endod. 2014, 40, 931-936. [CrossRef] [PubMed]

163. Nada, O.A.; El Backly, R.M. Stem Cells From the Apical Papilla (SCAP) as a Tool for Endogenous Tissue Regeneration. Front. Bioeng. Biotechnol. 2018, 24, 103. [CrossRef]

164. Miller, A.A.; Takimoto, K.; Wealleans, J.; Diogenes, A. Effect of 3 Bioceramic Materials on Stem Cells of the Apical Papilla Proliferation and Differentiation Using a Dentin Disk Model. J. Endod. 2018, 44, 599-603. [CrossRef]

165. Wongwatanasanti, N.; Jantarat, J.; Sritanaudomchai, H.; Hargreaves, K.M. Effect of Bioceramic Materials on Proliferation and Odontoblast Differentiation of Human Stem Cells from the Apical Papilla. J. Endod. 2018, 44, 1270-1275. [CrossRef]

166. Zhang, J.; Ding, H.; Liu, X.; Sheng, Y.; Liu, X.; Jiang, C. Dental Follicle Stem Cells: Tissue Engineering and Immunomodulation. Stem Cells Dev. 2019, 28, 986-994. [CrossRef]

167. Shoi, K.; Aoki, K.; Ohya, K.; Takagi, Y.; Shimokawa, H. Characterization of pulp and follicle stem cells from impacted supernumerary maxillary incisors. Pediatr. Dent. 2014, 36, 79-84.

168. Rezai-Rad, M.; Bova, J.F.; Orooji, M.; Pepping, J.; Qureshi, A.; Del Piero, F.; Hayes, D.; Yao, S. Evaluation of bone regeneration potential of dental follicle stem cells for treatment of craniofacial defects. Cytotherapy 2015, 17, 1572-1581. [CrossRef] [PubMed]

169. Honda, M.J.; Imaizumi, M.; Tsuchiya, S.; Morsczeck, C. Dental follicle stem cells and tissue engineering. J. Oral Sci. 2010, 52, 541-552. [CrossRef] [PubMed]

170. Caracappa, J.D.; Gallicchio, V.S. The future in dental medicine: Dental stem cells are a promising source for tooth and tissue engineering. J. Stem Cell Res. 2019, 5, 30-36. [CrossRef] 
171. Yalvaç, M.E.; Ramazanoglu, M.; Tekguc, M.; Bayrak, O.F.; Shafigullina, A.K.; Salafutdinov, I.I.; Blatt, N.L.; Kiyasov, A.P.; Sahin, F.; Palotás, A.; et al. Human tooth germ stem cells preserve neuro-protective effects after long-term cryo-preservation. Curr. Neurovasc. Res. 2010, 7, 49-58. [CrossRef]

172. Yalvac, M.E.; Ramazanoglu, M.; Rizvanov, A.A.; Sahin, F.; Bayrak, O.F.; Salli, U.; Palotás, A.; Kose, G.T. Isolation and characterization of stem cells derived from human third molar tooth germs of young adults: Implications in neo-vascularization, osteo-, adipo- and neurogenesis. Pharm. J. 2010, 10, 105-113. [CrossRef]

173. Doğan, A.; Demirci, S.; Şahin, F. In vitro differentiation of human tooth germ stem cells into endothelial- and epithelial-like cells. Cell Biol. Int. 2015, 39, 94-103. [CrossRef]

174. Jeon, M.; Song, J.S.; Choi, B.J.; Choi, H.J.; Shin, D.M.; Jung, H.S.; Kim, S.O. In vitro and in vivo characteristics of stem cells from human exfoliated deciduous teeth obtained by enzymatic disaggregation and outgrowth. Arch. Oral Biol. 2014, 59, 1013-1023. [CrossRef]

175. Araújo, L.B.; Cosme-Silva, L.; Fernandes, A.P.; Oliveira, T.M.; Cavalcanti, B.D.N.; Gomes Filho, J.E.; Sakai, V.T. Effects of mineral trioxide aggregate, BiodentineTM and calcium hydroxide on viability, proliferation, migration and differentiation of stem cells from human exfoliated deciduous teeth. J. Appl. Oral Sci. 2018, 26, e20160629. [CrossRef]

176. Ma, L.; Makino, Y.; Yamaza, H.; Akiyama, K.; Hoshino, Y.; Song, G.; Kukita, T.; Nonaka, K.; Shi, S.; Yamaza, T. Cryopreserved dental pulp tissues of exfoliated deciduous teeth is a feasible stem cell resource for regenerative medicine. PLoS ONE 2012, 7, e51777. [CrossRef]

177. Kunimatsu, R.; Nakajima, K.; Awada, T.; Tsuka, Y.; Abe, T.; Ando, K.; Hiraki, T.; Kimura, A.; Tanimoto, K. Comparative characterization of stem cells from human exfoliated deciduous teeth, dental pulp, and bone marrow-derived mesenchymal stem cells. Biochem. Biophys. Res. Commun. 2018, 501, 193-198. [CrossRef]

178. Ching, H.S.; Luddin, N.; Rahman, I.A.; Ponnuraj, K.T. Expression of Odontogenic and Osteogenic Markers in DPSCs and SHED: A Review. Curr. Stem Cell Res. 2017, 12, 71-79. [CrossRef]

179. Miura, M.; Gronthos, S.; Zhao, M.; Lu, B.; Fisher, L.W.; Robey, P.G.; Shi, S. SHED: Stem cells from human exfoliated deciduous teeth. Proc. Natl. Acad. Sci. USA 2003, 100, 5807-5812. [CrossRef]

180. Martinez Saez, D.; Sasaki, R.T.; Neves, A.D.; da Silva, M.C. Stem Cells from Human Exfoliated Deciduous Teeth: A Growing Literature. Cells Tissues Organs 2016, 202, 269-280. [CrossRef] [PubMed]

181. Annibali, S.; Cristalli, M.P.; Tonoli, F.; Polimeni, A. Stem cells derived from human exfoliated deciduous teeth: A narrative synthesis of literature. Eur. Rev. Med. Pharmacol. Sci. 2014, 18, 2863-2881. [PubMed]

182. Arora, V.; Arora, P.; Munshi, A.K. Banking stem cells from human exfoliated deciduous teeth (SHED): Saving for the future. J. Clin. Pediatr. Dent. 2009, 2, 289-294. [CrossRef]

183. Mason, S.; Tarle, S.A.; Osibin, W.; Kinfu, Y.; Kaigler, D. Standardization and safety of alveolar bone-derived stem cell isolation. J. Dent. Res. 2014, 93, 55-61. [CrossRef]

184. Liu, Y.; Wang, H.; Dou, H.; Tian, B.; Li, L.; Jin, L.; Zhang, Z.; Hu, L. Bone regeneration capacities of alveolar bone mesenchymal stem cells sheet in rabbit calvarial bone defect. J. Tissue Eng. 2020, 11, 2041731420930379. [CrossRef]

185. Pekovits, K.; Kröpfl, J.M.; Stelzer, I.; Payer, M.; Hutter, H.; Dohr, G. Human mesenchymal progenitor cells derived from alveolar bone and human bone marrow stromal cells: A comparative study. Histochem. Cell Biol. 2013, 140, 611-621. [CrossRef]

186. Matsubara, T.; Suardita, K.; Ishii, M.; Sugiyama, M.; Igarashi, A.; Oda, R.; Nishimura, M.; Saito, M.; Nakagawa, K.; Yamanaka, K.; et al. Alveolar bone marrow as a cell source for regenerative medicine: Differences between alveolar and iliac bone marrow stromal cells. J. Bone Miner. Res. 2005, 20, 399-409. [CrossRef]

187. Park, J.C.; Kim, J.C.; Kim, Y.T.; Choi, S.H.; Cho, K.S.; Im, G.I.; Kim, B.S.; Kim, C.S. Acquisition of human alveolar bone-derived stromal cells using minimally irrigated implant osteotomy: In vitro and in vivo evaluations. J. Clin. Periodontol. 2012, 39, 495-505. [CrossRef]

188. Lim, K.T.; Hexiu, J.; Kim, J.; Seonwoo, H.; Choung, P.H.; Chung, J.H. Synergistic effects of orbital shear stress on in vitro growth and osteogenic differentiation of human alveolar bone-derived mesenchymal stem cells. BioMed Res. Int. 2014, 2014, 316803. [CrossRef] [PubMed]

189. Khazaei, M.; Bozorgi, A.; Khazaei, S.; Khademi, A. Stem cells in dentistry, sources, and applications. Dent. Hypotheses 2016, 7, 42-52. [CrossRef] 
190. Zhang, Q.; Shi, S.; Liu, Y.; Uyanne, J.; Shi, Y.; Shi, S.; Le, A.D. Mesenchymal stem cells derived from human gingiva are capable of immunomodulatory functions and ameliorate inflammation-related tissue destruction in experimental colitis. J. Immunol. 2009, 183, 7787-7798. [CrossRef] [PubMed]

191. Tomar, G.B.; Srivastava, R.K.; Gupta, N.; Barhanpurkar, A.P.; Pote, S.T.; Jhaveri, H.M.; Mishra, G.C.; Wani, M.R. Human gingiva-derived mesenchymal stem cells are superior to bone marrow-derived mesenchymal stem cells for cell therapy in regenerative medicine. Biochem. Biophys. Res. Commun. 2010, 393, 377-383. [CrossRef]

192. Tang, L.; Li, N.; Xie, H.; Jin, Y. Characterization of mesenchymal stem cells from human normal and hyperplastic gingiva. J. Cell. Physiol. 2011, 226, 832-842. [CrossRef]

193. Wang, F.; Yu, M.; Yan, X.; Wen, Y.; Zeng, Q.; Yue, W.; Yang, P.; Pei, X. Gingiva-derived mesenchymal stem cell-mediated therapeutic approach for bone tissue regeneration. Stem Cells Dev. 2011, 20, 2093-2102. [CrossRef]

194. Marynka-Kalmani, K.; Treves, S.; Yafee, M.; Rachima, H.; Gafni, Y.; Cohen, M.A.; Pitaru, S. The lamina propria of adult human oral mucosa harbors a novel stem cell population. Stem Cells 2010, 28, 984-995. [CrossRef]

195. Zhang, Q.Z.; Su, W.R.; Shi, S.H.; Wilder-Smith, P.; Xiang, A.P.; Wong, A.; Nguyen, A.L.; Kwon, C.W.; Le, A.D. Human gingiva-derived mesenchymal stem cells elicit polarization of $\mathrm{m} 2$ macrophages and enhance cutaneous wound healing. Stem Cells 2010, 28, 1856-1868. [CrossRef]

196. Murray, P.E.; Garcia-Godoy, F.; Hargreaves, K.M. Regenerative endodontics: A review of current status and a call for action. J. Endod. 2007, 33, 377-390. [CrossRef]

197. Trope, M. Regenerative Potential of Dental Pulp. J. Endod. 2008, 34, S13-S17. [CrossRef]

198. Hargreaves, K.M.; Diogenes, A.; Teixeira, F.B. Treatment options: Biological basis of regenerative endodontic procedures. Pediatr. Dent. 2013, 35, 129-140. [CrossRef]

199. Ding, R.Y.; Cheung, G.S.; Chen, J.; Yin, X.Z.; Wang, Q.Q.; Zhang, C.F. Pulp revascularization of immature teeth with apical periodontitis: A clinical study. J. Endod. 2009, 35, 745-749. [CrossRef]

200. Cvek, M. Prognosis of luxated non-vital maxillary incisors treated with calcium hydroxide and filled with gutta-percha. A retrospective clinical study. Endod. Dent. Traumatol. 1992, 8, 45-55. [CrossRef]

201. Andreasen, J.O.; Farik, B.; Munksgaard, E.C. Long-term calcium hydroxide as a root canal dressing may increase risk of root fracture. Dent. Traumatol. 2002, 18, 134-137. [CrossRef] [PubMed]

202. Nosrat, A.; Seifi, A.; Asgary, S. Regenerative Endodontic Treatment (Revascularization) for Necrotic Immature Permanent Molars: A Review and Report of Two Cases with a New Case Reports in Dentistry 5 Biomaterial. J. Endod. 2011, 37, 562-567. [CrossRef] [PubMed]

203. Nygaard-Ostby, B. The role of the blood in endodontic therapy. An experimental histological study. Acta Odontol. Scand. 1961, 19, 324-353. [CrossRef]

204. Nygarrd-Ostby, B.; Hjortdal, O. Tissue formation in the root canal following pulp removal. Scand. J. Dent. Res. 1971, 79, 333-349. [CrossRef]

205. Banchs, F.; Trope, M. Revascularization of immature permanent tooth with apical periodontitis: New treatment protocol? J. Endod. 2004, 30, 196-200. [CrossRef]

206. Kling, M.; Cvek, M.; Mejare, I. Rate and predictability of pulp revascularization in therapeutically reimplanted permanent incisors. Endod. Dent. Traumatol. 1986, 2, 83-89. [CrossRef]

207. Hoshino, E.; Kurihara-Ando, N.; Sato, I.; Uematsu, H.; Sato, M.; Kota, K.; Iwaku, M. In-vitro antibacterial susceptibility of bacteria taken from infected root dentine to a mixture of ciprofloxacin, metronidazole and minocycline. Endod. J. 1996, 29, 125-130. [CrossRef]

208. Nakashima, M.; Akifumi, A. The Application of Tissue Engineering to Regeneration of Pulp and Dentin in Endodontics. J. Endod. 2005, 31, 711-718. [CrossRef] [PubMed]

209. American Association of Endodontists. AAE Clinical Considerations for a Regenerative Procedure Revised 4/1/2018. Available online: https://www.aae.org/specialty/wp-content/uploads/sites/2/2018/06/ ConsiderationsForRegEndo_AsOfApril2018.pdf (accessed on 15 October 2020).

210. Hargreaves, K.M.; Cohen, S.; Berman, L.H. (Eds.) Cohen's Pathways of the Pulp, 10th ed.; Mosby Elsevier: St. Louis, MI, USA, 2011; pp. 602-618.

211. Jung, C.; Kim, S.; Sun, T.; Cho, Y.B.; Song, M. Pulp-dentin regeneration: Current approaches and challenges. J. Tissue Eng. 2019, 10, 2041731418819263. [CrossRef] [PubMed] 
212. Prescott, R.S.; Alsanea, R.; Fayad, M.I.; Johnson, B.R.; Wenckus, C.S.; Hao, J.; John, A.S.; George, A. In Vivo Generation of Dental Pulp-like Tissue by Using Dental Pulp Stem Cells, a Collagen Scaffold, and Dentin Matrix Protein 1 after Subcutaneous Transplantation in Mice. J. Endod. 2008, 34, 421-426. [CrossRef] [PubMed]

213. Kim, J.Y.; Xin, X.; Moioli, E.K.; Chung, J.; Lee, C.H.; Chen, M.; Fu, S.Y.; Koch, P.D.; Mao, J.J. Regeneration of Dental-Pulp-like Tissue by Chemotaxis-Induced Cell Homing. Tissue Eng. Part A 2010, 16, 3023-3031. [CrossRef]

214. Fouad, A.F. Microbial factors and antimicrobial strategies in dental pulp regeneration. J. Endod. 2007, 43, 46-50. [CrossRef]

215. Estefan, B.S.; El Batouty, K.M.; Nagy, M.M.; Diogenes, A. Influence of age and apical diameter on the success of endodontic regeneration procedures. J. Endod. 2016, 42, 1620-1625. [CrossRef]

216. Fang, Y.; Wang, X.; Zhu, J.; Su, C.; Yang, Y.; Meng, L. Influence of apical diameter on the outcome of regenerative endodontic treatment in teeth with pulp necrosis: A review. J. Endod. 2018, 44, 414-431. [CrossRef]

217. Kim, S.G. Infection and pulp regeneration. Dent. J. 2016, 4, 4. [CrossRef]

218. Iwaya, S.I.; Ikawa, M.; Kubota, M. Revascularization of an immature permanent tooth with apical periodontitis and sinus tract. Dent Traumatol. 2001, 17, 185-187. [CrossRef]

219. Chen, M.Y.H.; Chen, K.L.; Chen, C.A.; Tayebaty, F.; Rosenberg, P.A.; Lin, L.M. Responses of immature permanent teeth with infected necrotic pulp tissue and apical periodontitis/abscess to revascularization procedures. Int. Endod. J. 2012, 45, 294-305. [CrossRef]

220. Lin, L.M.; Shimizu, E.; Gibbs, J.L.; Loghin, S.; Ricucci, D. Histologic and histobacteriologic observations of failed revascularization/revitalization therapy: A case report. J. Endod. 2014, 40, 291-295. [CrossRef] [PubMed]

221. Haapasalo, M.; Shen, Y. Current therapeutic options for endodontic biofilms. Endod. Top. 2010, 22, 79-98. [CrossRef]

222. Haapasalo, M.; Endal, U.; Zandi, H.; Coil, J.M. Eradication of endodontic infection by instrumentation and irrigation solutions. Endod. Top. 2005, 10, 77-102. [CrossRef]

223. Fouad, A.F.; Nosrat, A. Pulp regeneration in previously infected root canal space. Endod. Top. 2013, $28,24-37$. [CrossRef]

224. Diogenes, A.; Henry, M.A.; Teixeira, F.B.; Hargreaves, K.M. An update on clinical regenerative endodontics. Endod. Top. 2013, 28, 2-23. [CrossRef]

225. Haapasalo, M.; Shen, Y.; Qian, W.; Gao, Y. Irrigation in endodontics. Dent. Clin. N. Am. 2010, 54, $291-312$. [CrossRef]

226. Spratt, D.A.; Pratten, J.; Wilson, M.; Gulabivala, K. An in vitro evaluation of antimicrobial efficacy of irrigants on biofilm of root canal isolates. Int. Endod. J. 2001, 34, 300-307. [CrossRef]

227. Sena, N.T.; Gomes, B.P.F.A.; Vianna, M.E.; Berber, V.B.; Zaia, A.A.; Ferraz, C.C.R.; Souza-Filho, F.J. In vitro antimicrobial activity of sodium hypochlorite and chlorhexidine against selected single-species biofilms. Int. Endod. J. 2006, 39, 878-885. [CrossRef]

228. Trevino, E.G.; Patwardhan, A.N.; Henry, M.A.; Perry, G.; Dybdal-Hargreaves, N.; Hargreaves, K.M.; Diogenes, A. Effect of irrigants on the survival of human stem cells of the apical papilla in a platelet-rich plasma scaffold in human root tips. J. Endod. 2011, 37, 1109-1115. [CrossRef]

229. Martin, D.E.; De Almeida, J.F.A.; Henry, M.A.; Khaing, Z.Z.; Schmidt, C.E.; Teixeira, F.B.; Diogenes, A. Concentration-dependent effect of sodium hypochlorite on stem cells of apical papilla survival and differentiation. J. Endod. 2014, 40,51-55. [CrossRef]

230. Galler, K.M.; Widbiller, M.; Buchalla, W.; Eidt, A.; Hiller, K.-A.; Hoffer, P.C.; Schmalz, G. EDTA conditioning of dentine promotes adhesion, migration and differentiation of dental pulp stem cells. Int. Endod. J. 2016, 49, 581-590. [CrossRef] [PubMed]

231. Neha, K.; Kansal, R.; Garg, P.; Joshi, R.; Garg, D.; Grover, H.S. Management of immature teeth by dentin-pulp regeneration: A recent approach. Med. Oral Patol. Oral Cir. Bucal. 2011, 16, 997-1004. [CrossRef]

232. Mohammad, Z.; Shalav, S.; Jafarzadeh, H. Ethyleneaminetetraacetic in endodontics. Eur. J. Dent. 2013, 7 (Suppl. 1), 135-142. [CrossRef]

233. Galler, K.M.; Buchalla, W.; Hiller, K.-A.; Federlin, M.; Eidt, A.; Schiefersteiner, M.; Schmalz, G. Influence of root canal disinfectants on growth factor release from dentin. J. Endod. 2015, 41, 363-368. [CrossRef] 
234. Galler, K.M.; D’Souza, R.N.; Federlin, M.; Cavender, A.C.; Hartgerink, J.D.; Hecker, S.; Schmalz, G. Dentin conditioning codetermines cell fate in regenerative endodontics. J. Endod. 2011, 37, 1536-1541. [CrossRef]

235. Vishwanat, L.; Duong, R.; Takimoto, K.; Phillips, L.; Espitia, C.O.; Diogenes, A.; Ruparel, S.B.; Kolodrubetz, D.; Ruparel, N.B. Effect of bacterial biofilm on the osteogenic differentiation of stem cells of apical papilla. J. Endod. 2017, 43, 916-922. [CrossRef]

236. Sonoyama, W.; Liu, Y.; Yamaza, T.; Tuan, R.S.; Wang, S.; Shi, S.; Huang, G.T.J. Characterization of apical papilla and its residing stem cells from human immature permanent teeth-A pilot study. J. Endod. 2008, 34, 166-171. [CrossRef]

237. Reynolds, K.; Johnson, J.D.; Cohenca, N. Pulp revascularization of necrotic bilateral bicuspids using a modified novel technique to eliminate potential coronal discolouration: A case report. Int. Endod. J. 2009, 42, 84-92. [CrossRef]

238. Assed Bezerra da Silva, L.; Assed Bezerra da Silva, R.; Nelson-Filho, P. Intracanal Medication in Root Canal Disinfection. Available online: https://pocketdentistry.com/13-intracanal-medication-in-root-canaldisinfection/ (accessed on 15 October 2020).

239. Wang, X.; Thibodeau, B.; Trope, M.; Lin, L.M.; Huang, G.T.J. Histologic characterization of regenerated tissues in canal space after the revitalization/revascularization procedure of immature dog teeth with apical periodontitis. J. Endod. 2010, 36, 56-63. [CrossRef]

240. Rybak, M.J.; McGrath, B.J. Combination Antimicrobial Therapy for Bacterial Infections. Drugs 1996, 52, 390-405. [CrossRef]

241. Baumgartner, J.C.; Xia, T. Antibiotic susceptibility of bacteria associated with endodontic abscesses. J. Endod. 2003, 29, 44-47. [CrossRef] [PubMed]

242. Mohammad, Z.; Dummer, P.M.H. Properties and application of calcium hydroxide in endodontics and dental traumatology. Int. Endod. J. 2011, 44, 697-730. [CrossRef]

243. Haapasalo, M.K.; Siren, E.K.; Waltimo, T.M.T.; Orstavik, D.; Haapasalo, M.P. Inactivation of local root canal medicaments by dentin: An in vitro study. Int. Endod. J. 2000, 33, 126-131. [CrossRef] [PubMed]

244. Haapasalo, M.K.; Qian, W.; Portnier, I.; Waltimo, T. Effect of dentin on antimicrobial properties of endodontic medicaments. J. Endod. 2007, 33, 917-925. [CrossRef]

245. Sathorn, C.; Parashos, P.; Messer, M. Antimicrobial efficacy of calcium hydroxide intracanal dressing: A systematic review and meta-analysis. Int. Endod. J. 2007, 40, 2-10. [CrossRef]

246. Aggarwal, V.; Miglani, S.; Singla, M. Conventional apexification and revascularization induced maturogenesis of two non-vital, immature teeth in same patient: 24 months follow up of a case. J. Conserv. Dent. 2012, 15, 68-72. [CrossRef]

247. Kitikuson, P.; Srisuwan, T. Attachment ability of human apical papilla cells to root dentin surfaces treated with either 3Mix or calcium hydroxide. J. Endod. 2016, 42, 89-94. [CrossRef]

248. Nevins, A.J.; Finkelstein, F.; Borden, B.G.; Laporta, R. Revitalization of pulpless open apex teeth in rhesus monkeys, using collagen-calcium phosphate gel. J. Endod. 1976, 2, 159-165. [CrossRef]

249. Simon, S.; Rilliard, F.; Berdal, A.; Machtou, P. The use of mineral trioxide aggregate in one-visit apexification treatment: A0 prospective study. Int. Endod. J. 2007, 40, 186-197.

250. Jadhav, G.R.; Shah, N.; Logani, A. Comparative outcome of revascularization in bilateral, non-vital, immature maxillary anterior teeth supplemented with or without platelet rich plasma: A case series. J. Conserv. Dent. 2013, 16, 568-572. [CrossRef]

251. Yamauchi, N.; Yamauchi, S.; Nagaoka, H.; Duggan, D.; Zhong, S.; Lee, S.M.; Teixeira, F.B.; Yamauchi, M. Tissue engineering strategies for immature teeth with apical periodontitis. J. Endod. 2011, 37, 390-397. [CrossRef] [PubMed]

252. Jung, I.Y.; Lee, S.J.; Hargreaves, K.M. Biologically based treatment of immature permanent teeth with pulpal necrosis: A case series. J. Endod. 2008, 34, 876-887. [CrossRef] [PubMed]

253. Lovelace, T.W.; Henry, M.A.; Hargreaves, K.M.; Diogenes, A. Evaluation of the delivery of mesenchymal stem cells into the root canal space of necrotic immature teeth after clinical regenerative endodontic procedure. J. Endod. 2011, 37, 133-138. [CrossRef] [PubMed] 
254. Huang, G.T.J.; Sonoyama, W.; Liu, Y.; Liu, H.; Wang, S.; Shi, S. The hidden treasure in apical papilla: The potential role in pulp/dentin regeneration and bioroot engineering. J. Endod. 2008, 34, 645-651. [CrossRef] [PubMed]

255. Miller, E.K.; Lee, J.Y.; Tawil, P.Z.; Teixeira, F.B.; Vann Jr, W.F. Emerging therapies for the management of traumatized immature permanent incisors. Pediatr. Dent. 2012, 34, 66-69. [PubMed]

256. Torabinejad, M.; Turman, M. Revitalization of tooth with necrotic pulp and open apex by using platelet-rich plasma: A case report. J. Endod. 2011, 37, 265-268. [CrossRef]

257. Cehreli, Z.C.; Isbitiren, B.; Sara, S.; Erbas, G. Regenerative endodontic treatment (revascularization) of immature necrotic molars medicated with calcium hydroxide: A case series. J. Endod. 2011, 37, 1327-1330. [CrossRef]

258. Nazir, M.A. Prevalence of periodontal disease, its association with systemic diseases and prevention. Int. J. Health Sci. 2017, 11, 72-80.

259. Galuscan, A.; Cornianu, M.; Jumanca, D.; Faur, A.; Podariu, A.; Ardelean, L.; Rusu, L.C. Evaluation of marginal periodontium adjacent to the reconstruction materials in the dental prosthetics. Study morphopathologycal and immunohistochemical. Mater. Plast. 2012, 49, 85-89.

260. Aimetti, M.; Perotto, S.; Castiglione, A.; Mariani, G.M.; Ferrarotti, F.; Romano, F. Prevalence of periodontitis in an adult population from an urban area in North Italy: Findings from a cross-sectional population-based epidemiological survey. J. Clin. Periodontol. 2015, 42, 622-631. [CrossRef]

261. Kassebaum, N.J.; Bernabé, E.; Dahiya, M.; Bhandari, B.; Murray, C.J.; Marcenes, W. Global burden of severe periodontitis in 1990-2010: A systematic review meta-regression. J. Dent. Res. 2014, 93, 1045-1053. [CrossRef] [PubMed]

262. Matuliene, G.; Pjetursson, B.E.; Salvi, G.E.; Schmidlin, K.; Bragger, U.; Zwahlen, M.; Lang, N.P. Influence of residual pockets on progression of periodontitis and tooth loss: Results after 11 years of maintenance. J. Clin. Periodontol. 2008, 35, 685-695. [CrossRef] [PubMed]

263. Nevins, M.; Giannobile, W.V.; McGuire, M.K.; Kao, R.T.; Mellonig, J.T.; Hinrichs, J.E.; McAllister, B.S.; Murphy, K.S.; McClain, P.K.; Nevins, M.L.; et al. Platelet-derived growth factor stimulates bone fill and rate of attachment level gain: Results of a large multicenter randomized controlled trial. J. Periodontol. 2005, 76, 2205-2215. [CrossRef] [PubMed]

264. Siaili, M.; Chatzopoulou, D.; Gillam, D.G. An overview of periodontal regenerative procedures for the general dental practitioner. Saudi Dent. J. 2018, 30, 26-37. [CrossRef]

265. Yamada, Y.; Nakamura-Yamada, S.; Kusano, K.; Baba, S. Clinical potential and current progress of dental pulp stem cells for various systemic diseases in regenerative medicine: A concise review. Int. J. Mol. Sci. 2019, 20, 1132. [CrossRef]

266. Xu, X.; Li, X.; Wang, J.; He, X.T.; Sun, H.H.; Chen, F.M. Concise Review: Periodontal Tissue Regeneration Using Stem Cells: Strategies and Translational Considerations. Stem Cells Transl. Med. 2019, 8, $392-403$. [CrossRef]

267. Liang, Y.; Luan, X.; Liua, X. Recent advances in periodontal regeneration: A biomaterial perspective. Bioact. Mater. 2020, 5, 297-308. [CrossRef]

268. Murphy, K.G.; Gunsolley, J.C. Guided tissue regeneration for the treatment of periodontal intrabony and furcation defects. A systematic review. Ann. Periodontol. 2003, 8, 266-302. [CrossRef]

269. Needleman, I.G.; Worthington, H.V.; Giedrys-Leeper, E.; Tucker, R.J. Guided tissue regeneration for periodontal infra-bony defects. Chocrane Database Syst. Rev. 2006, 19, 1724. [CrossRef]

270. Kaushal, S.; Kumar, A.; Khan, M.A.; Lal, N. Comparative study of nonabsorbable and absorbable barrier membranes in periodontal osseous defects by guided tissue regeneration. J. Oral Biol. Craniofac. Res. 2016, 6, 111-117. [CrossRef]

271. Zhou, L.N.; Bi, C.S.; Gao, L.N. Macrophage polarization in human gingival tissue in response to periodontal disease. Oral Dis. 2019, 25, 265-273. [CrossRef] [PubMed]

272. Seciu, A.M.; Craciunescu, O.; Zarnescu, O. Advanced Regenerative Techniques Based on Dental Pulp Stem Cells for the Treatment of Periodontal Disease. In Periodontology and Dental Implantology; Manakil, J., Ed.; IntechOpen Limited: London, UK, 2018. [CrossRef]

273. Susin, C.; Wikesjo, U. Regenerative periodontal therapy: 30 years of lessons learned and unlearned. Periodontology 2000, 2013, 232-242. [CrossRef] 
274. Zhai, Q.; Dong, Z.; Wang, W.; Li, B.; Jin, Y. Dental stem cell and dental tissue regeneration. Front. Med. 2019, 13, 152-159. [CrossRef] [PubMed]

275. Raju, R.; Oshima, M.; Inoue, M.; Morita, T.; Huijiao, Y.; Waskitho, A.; Baba, O.; Inoue, M.; Matsuka, Y. Three-dimensional periodontal tissue regeneration using a bone-ligament complex cell sheet. Sci. Rep. 2020, 10,1-16. [CrossRef]

276. Iwata, T.; Yamato, M.; Washio, K.; Yoshida, T.; Tsumanuma, Y.; Yamada, A.; Onizuka, S.; Izumi, Y.; Ando, T.; Okano, T.; et al. Periodontal regeneration with autologous periodontal ligament-derived cell sheets-a safety and efficacy study in ten patients. Regen. Ther. 2018, 9, 38-44. [CrossRef] [PubMed]

277. Ausenda, F.; Rasperini, G.; Acunzo, R.; Gorbunkova, A.; Pagni, G. New Perspectives in the Use of Biomaterials for Periodontal Regeneration. Materials 2019, 12, 2197. [CrossRef]

278. Sheikh, Z.; Hamdan, N.; Ikeda, Y.; Grynpas, M. Natural graft tissues and synthetic biomaterials for periodontal and alveolar bone reconstructive applications: A review. Biomater. Res. 2017, 21-29. [CrossRef]

279. Liu, J.; Ruan, J.; Weir, M.D.; Ren, K.; Schneider, A.; Wang, P.; Oates, T.W.; Chan, X.; Xu, H.H. Periodontal bone-ligament-cementum regeneration via scaffolds and stem cells. Cells 2019, 8, 537. [CrossRef]

280. Belinfante, L.S. The History of Oral and Maxillofacial Surgery. In Current Therapy In Oral and Maxillofacial Surgery; Bagheri, S.C., Bell, R.B., Ali Khan, H., Eds.; Elsevier: Amsterdam, The Netherlands, 2012; pp. 1-5.

281. Aghaloo, T.L.; Felnsfeld, A.L. Principles of Repair and Grafting of Bone and Cartilage. In Current Therapy In Oral and Maxillofacial Surgery; Bagheri, S.C., Bell, R.B., Ali Khan, H., Eds.; Elsevier: Amsterdam, The Netherlands, 2012; pp. 19-26.

282. Keyhan, S.O.; Fallahi, H.; Jahangirnia, A.; Masoumi, S.M.R.; Khosravi, M.H.; Amirzade-Iranaq, M.H. Tissue Engineering Applications in Maxillofacial Surgery. In Stem Cells in Clinical Practice and Tissue Engineering; Sharma, R., Ed.; IntechOpen: London, UK, 2017; pp. 271-291.

283. Zhang, Q.; Nguyen, P.D.; Shi, S.; Burrell, J.C.; Cullen, D.K.; Le, A.D. 3D bioprinted scaffold-free nerve constructs with human gingiva-derived mesenchymal stem cells promote rat facial nerve regeneration. Sci. Rep. 2018, 8, 6634. [CrossRef]

284. Li, J.; Xu, S.Q.; Zhang, K.; Zhang, W.J.; Liu, H.L.; Xu, Z.; Li, H.; Lou, J.N.; Ge, L.H.; Xu, B.H. Treatment of gingival defects with gingival mesenchymal stem cells derived from human fetal gingival tissue in a rat model. Stem Cell Res. 2018, 9, 27. [CrossRef]

285. Triplett, R.G.; Schow, S.R. Autologous bone grafts and endosseous implants: Complementary techniques. J. Oral Maxillofac. Surg. 1996, 54, 486-494. [CrossRef] [PubMed]

286. Wu, V.; Helder, M.N.; Bravenboer, N.; Ten Bruggenkate, C.M.; Jin, J.; Klein-Nulend, J.; Schulten, E.A. Bone tissue regeneration in the oral and maxillofacial region: A review on the application of stem cells and new strategies to improve vascularization. Stem Cells Int. 2019, 2019, 6279721. [CrossRef] [PubMed]

287. Trubiani, O.; Marconi, G.D.; Pierdomenico, S.D.; Piattelli, A.; Diomede, F.; Pizzicannella, J. Human Oral Stem Cells, Biomaterials and Extracellular Vesicles: A Promising Tool in Bone Tissue Repair. Int. J. Mol. Sci. 2019, 20, 4987. [CrossRef]

288. Iaquinta, M.R.; Mazzoni, E.; Bononi, I.; Rotondo, J.C.; Mazziotta, C.; Montesi, M.; Sprio, S.; Tampieri, A.; Martini, F. Adult stem cells for bone regeneration and repair. Front. Cell Dev. Biol. 2019, 7, 268. [CrossRef] [PubMed]

289. Chocholata, P.; Kulda, V.; Babuska, V. Fabrication of scaffolds for bone-tissue regeneration. Materials 2019, 12, 568. [CrossRef]

290. Ceccarelli, G.; Presta, R.; Benedetti, L.; Cusella De Angelis, M.G.; Lupi, S.M.; Rodriguez y Baena, R. Emerging perspectives in scaffold for tissue engineering in oral surgery. Stem Cells Int. 2017, 2017, 4585401. [CrossRef] [PubMed]

291. Rodriguez y Baena, R.; D'Aquino, R.; Graziano, A. Autologous periosteum-derived micrografts and PLGA/HA enhance the bone formation in sinus lift augmentation. Front. Cell Dev. Biol. 2017, 5, 87. [CrossRef]

292. Mohammed, E.E.A.; El-Zawahry, M.; Farrag, A.R.H.; Aziz, N.N.A.; Sharaf El-Din, W.; Abu-Shahba, N.; Mahmoud, M.; Gaber, K.; Ismail, T.; Mossaad, M.M.; et al. Osteogenic Differentiation potential of human bone marrow and amniotic fluid-derived mesenchymal stem cells in vitro \& in vivo. Maced. J. Med. Sci. 2019, 7, 507-515. [CrossRef] 
293. Mazzoni, E.; D’Agostino, A.; Iaquinta, M.R.; Bononi, I.; Trevisiol, L.; Rotondo, J.C.; Patergani, S.; Giorgi, C.; Gunson, M.; Arnett, G.W.; et al. Hydroxylapatite-collagen hybrid scaffold induces human adipose-derived mesenchymal stem cells (hASCs) to osteogenic differentiation in vitro and bone re-growth in patients. Stem Cells Transl. Med. 2019, 9, 377-388. [CrossRef]

294. Park, Y.J.; Cha, S.; Park, Y.S. Regenerative applications using tooth derived stem cells in other than tooth regeneration: A literature review. Stem Cells Int. 2016, 2016, 9305986. [CrossRef]

295. Diomede, F.; Gugliandolo, A.; Cardelli, P.; Merciaro, I.; Ettorre, V.; Traini, T.; Bedini, R.; Scionti, D.; Bramanti, A.; Nanci, A.; et al. Three-dimensional printed PLA scaffold and human gingival stem cell-derived extracellular vesicles: A new tool for bone defect repair. Stem Cell Res. 2018, 9, 104. [CrossRef]

296. Sakkas, A.; Wilde, F.; Heufelder, M.; Winter, K.; Schramm, A. Autogenous bone grafts in oral implantology-Is it still a "gold standard"? A consecutive review of 279 patients with 456 clinical procedures. Int. J. Implant. Dent. 2017, 3, 23. [CrossRef] [PubMed]

297. Gjerde, C.; Mustafa, K.; Hellem, S.; Rojewski, M.; Gjengedal, H.; Yassin, M.A.; Feng, X.; Skaale, S.; Berge, T.; Rosen, A.; et al. Cell therapy induced regeneration of severely atrophied mandibular bone in a clinical trial. Stem Cell Res. 2018, 9, 213. [CrossRef]

298. Di Stefano, D.A.; Greco, G.B.; Riboli, F. Guided Bone Regeneration of an Atrophic Mandible with a Heterologous Bone Block. Craniomaxillofac. Trauma Reconstr. 2016, 9, 88-93. [CrossRef] [PubMed]

299. McGuire, T.P.; Rittenberg, B.N.; Baker, G.I. Surgery for Disorders of the Temporomandibular Joint. Available online: https://www.oralhealthgroup.com/features/surgery-for-disorders-of-the-temporomandibular-joint/ (accessed on 15 October 2020).

300. Jazayeri, H.E.; Tahriri, M.; Razavi, M.; Khoshroo, K.; Fahimipour, F.; Dashtimoghadam, E.; Almeida, L.; Tayebi, L. A current overview of materials and strategies for potential use in maxillofacial tissue regeneration. Mater. Sci. Eng. 2017, 70, 913-929. [CrossRef]

301. Shetty, L.; Badhe, R.V.; Bhonde, R.; Waknis, P.; Londhe, U. Chitosan and stemcells: A synchrony for regeneration. J. Dent. Res. Rev. 2020, 7, 95-97. [CrossRef]

302. Oshima, M.; Tsuji, T. Whole Tooth Regeneration Using a Bioengineered Tooth. In New Trends in Tissue Engineering and Regenerative Medicine-Official Book of the Japanese Society for Regenerative Medicine; Hibi, H., Ueda, M., Eds.; IntechOpen: London, UK, 2014. [CrossRef]

303. Wu, Z.; Wang, F.; Fan, Z.; Wu, T.; He, J.; Wang, J.; Zhang, C.; Wang, S. Whole-Tooth Regeneration by Allogeneic Cell Reassociation in Pig Jawbone. Tissue Eng. Part A 2019, 25, 1202-1212. [CrossRef]

304. Ikeda, E.; Morita, R.; Nakao, K.; Ishida, K.; Nakamura, T.; Takano-Yamamoto, T.; Ogawab, M.; Mizunoa, M.; Kasugaie, S.; Tsujia, T. Fully functional bioengineered tooth replacement as an organ replacement therapy. Proc. Natl. Acad. Sci. USA 2009, 106, 13475-13480.

305. Nakao, K.; Tsuji, T. Dental regenerative therapy: Stem cell transplantation and bioengineered tooth replacement. Jpn. Dent. Sci. Rev. 2008, 44,70-75. [CrossRef]

306. Zhang, L.; Morsi, Y.; Wang, Y.; Li, Y.; Ramakrishna, S. Review scaffold design and stem cells for tooth regeneration. Jpn. Dent. Sci. Rev. 2013, 49, 14-26. [CrossRef]

307. Ono, M.; Oshima, M.; Ogawa, M.; Sonoyama, W.; Hara, E.S.; Oida, Y.; Shinkawa, S.; Nakajima, R.; Mine, A.; Fukumoto, S. Practical whole-tooth restoration utilizing autologous bioengineered tooth germ transplantation in a postnatal canine model. Sci. Rep. 2017, 7, 44522. [CrossRef] [PubMed]

308. Thesleff, I. From understanding tooth development to bioengineering of teeth. Eur. J. Oral Sci. 2018, 126, 67-71. [CrossRef] [PubMed]

309. Yelick, P.C.; Sharpe, P.T. Tooth Bioengineering and Regenerative Dentistry. J. Dent. Res. 2019, 98, 1173-1182. [CrossRef] [PubMed]

310. Oshima, M.; Inoue, K.; Nakajima, K.; Tachikawa, T.; Yamazaki, H.; Isobe, T.; Sugawara, A.; Ogawa, M.; Tanaka, C.; Saito, M.; et al. Functional tooth restoration by next generation bio-hybrid implants a bio-hybrid artificial organ replacement therapy. Sci. Rep. 2014, 4, 6044. [CrossRef] [PubMed]

311. Wei, F.; Song, T.; Ding, G.; Xu, J.; Liu, Y.; Liu, D.; Fan, Z.; Zhang, C.; Shi, S.; Wang, S. Functional tooth restoration by allogeneic mesenchymal stem cell-based bio-root regeneration in swine. Stem Cells Dev. 2013, 22, 1752-1762. [CrossRef] 
312. Rusu, L.C.; Ardelean, L.; Negrutiu, M.L.; Dragomirescu, A.O.; Albu, M.G.; Ghica, M.V.; Topala, F.I.; Podoleanu, A.; Sinescu, C. SEM for the general structural features assesing of the synthetic polymer scaffolds. Rev. Chim. 2011, 62, 841-845.

Publisher's Note: MDPI stays neutral with regard to jurisdictional claims in published maps and institutional affiliations.

(C) 2020 by the authors. Licensee MDPI, Basel, Switzerland. This article is an open access article distributed under the terms and conditions of the Creative Commons Attribution (CC BY) license (http://creativecommons.org/licenses/by/4.0/). 